\title{
OPIEKA DUSZPASTERSKA NAD POLAKAMI W DANII (1892-1939)
}

Początki opieki duszpasterskiej nad wychodźstwem polskim w Danii sięgają przełomu XIX i XX stulecia. Zagadnienie to przybliżyli w swoich opracowaniach polskiemu czytelnikowi m.in.: W. Chojnacki ${ }^{1}$, A. Jędrzejowski ${ }^{2}$, E.S. Kruszewski ${ }^{3}$, S. Kościelecka ${ }^{4}$, E. Olszewski ${ }^{5}$, J. Szymaszek ${ }^{6}$, W. Zdunek ${ }^{7}$, A. Stasiak ${ }^{8}$, E. Later-Chodyłowa ${ }^{9}$, B. Kołodziej ${ }^{10}$, J. Szymański ${ }^{11}$, G. Nellemann ${ }^{12}$, J. Malanowski ${ }^{13}$.

Ks. dr hab. JóZEF SzYMAŃSKI, prof. AP - Instytut Historii, https://orcid.org/0000-0003-3799-200X

1 Stan i potrzeby badań nad Polonia duńska, ,Przegląd Zachodni” 1977, nr 5/6, s. 131-134; TENŻE, Materiaty do bibliografii Polonii duńskiej, „Przegląd Zachodni” 1974, nr 2, s. 340-361.

2 Polonia duńska w latach 1892-1921, „Przegląd Polonijny” 1(1975), z. 2, s. 17-31.

3 Problemy osadnictwa Polaków w Danii 1893-1939, Londyn 1980; TENże, Pastor Edward Ortved (1855-1930) og Hans breve til biskop Johannes von Euch fra 1894-1906. Ksiadz Edward Ortved (1855-1930) oraz listy z lat 1894-1906 do bp. Johannes von Eucha, Kobenhavn 2003; TENŻE, Śladami polskiego apostolstwa w Danii, [w:] W nieustającej trosce o polska diasporę: tom studiów historycznych i politologicznych dedykowany Księdzu Arcybiskupowi Szczepanowi Wesołemu, red. R. Nir, M. Szczerbiński, K. Wasilewski, Gorzów Wielkopolski 2012, s. 149-164.

${ }^{4}$ Dzieje Polonii w Danii w latach 1892-1940, Szczecin 1983.

5 Emigracja polska w Danii 1893-1993, Warszawa-Lublin 1993; Polacy w Skandynawii, red. E. Olszewski, Lublin 1997, s. 99-163.

${ }^{6}$ Duszpasterstwo polskie w Danii. Szkic historyczny, „Duszpasterz Polski Zagranicą” 25(1974), z. 2(111), s. 164-175.

7 Duszpasterstwo Polaków w Danii (1893-1978), „Studia Polonijne” 5(1982), s. 145-177.

${ }^{8}$ Opieka duszpasterska nad polska emigracją zarobkowa w Danii w latach 1893-1939, Kraków 1982.

9 Liczebność i rozmieszczenie emigracji polskiej w Danii w latach 1893-1940, „Przegląd Polonijny” 17(1991), z. 3, s. 19-30; TAŻ, Przegląd literatury na temat dziejów Polaków i Polonii w Danii, „Przegląd Polsko-Polonijny” 3(2012), z. 3, s. 279-302.

10 Opieka duszpasterska nad wychodźcami polskimi do roku 1939, Poznań 2003, s. 300-305.

${ }^{11}$ Z dziejów opieki duszpasterskiej nad Polakami w Danii w 1927 roku, „Studia Polonijne” 33(2012), s. 155-168; TENŻE, Związek Robotników Polskich w Danii w trosce o zachowanie tożsamości narodowej rodaków w 1933 roku, „Studia Polonijne” 34(2013), s. 167-180. 
Emigracja do Danii wynikała z przybycia polskich robotników sezonowych w 1892 r. Pierwszą wiadomość o niej podał wrześniowy „Przegląd Emigracyjny”: „Polscy robotnicy w Danii w liczbie $30^{14}$ przybyli w sierpniu za namową agentów do jednej z duńskich wysp bałtyckich, aby tam pomagać podczas żniw i przy tym coś na zimę zarobić. [...] W roku bieżącym zrobiono próbę pierwszą z Polakami"15. Co odnotowano również na łamach „Tygodnika Ilustrowanego": „Od r. 1892, kolonia katolicka zwiększać się zaczęła wskutek napływu wychodźców polskich, przybywających do Danii na roboty rolne" ${ }^{16}$. Niemniej, większość dotychczasowych autorów, omawiających polską emigrację w Danii, przyjmuje rok 1893 jako początek zorganizowanej emigracji zarobkowej, trwającej z przerwami do 1929 r. Jakkolwiek zdaniem Janusza Wasilkowskiego: „Pierwsza grupa polskich robotników przybyła do Danii w 1892 r. Liczyła ponoć 500 osób (choć niektóre ówczesne źródła podają liczbę 30 przybyszy). [...] Przyjmuje się, że do czasu I Wojny Światowej zanotowano z terenów polskich ponad 100 tys. przyjazdów, trudno jednak o wiarygodne dane, ilu z tych sezonowych przybyszy przebywało w Danii kilka lub kilkanaście razy. Część przybyłych do Danii dziewcząt nie wracała do kraju, wychodząc za mąż za Duńczyków i uzyskując dzięki temu duńskie obywatelstwo" $" 17$

W 1893 r. na wyspy Lolland i Falster przybyła pierwsza większa grupa Polaków ${ }^{18}$. W ciągu następnych lat wyspy te były punktem docelowym większości polskich robotników, którzy zamieszkali i podjęli pracę w Mariebjerg, Vindeby, Horslunde, Vesterorg, Stokkemarke, Ryde, Opager i Kappel. Część robotników wędrowała dalej, znajdując zatrudnienie na Zelandii, Fynie, Langelandzie oraz w Jutlandii i na Bornholmie ${ }^{19}$. W latach następnych liczba sezonowych emigrantów sy-

12 Polscy robotnicy rolni w Danii, „Przegląd Polonijny” 9(1985), z. 1, s. 5-30; TENżE, Polska emigracja zarobkowa w Danii od r. 1893, „Przegląd Zachodni” 29(1973), z. 1, s. 41-71.

13 Adaptacja Polaków w Danii, „Problemy Polonii Zagranicznej” 1(1961), s. 124-154.

${ }^{14}$ Cytaty z zachowaniem oryginalnego stylu, składni i ortografii.

${ }^{15}$ Polscy robotnicy w Danii, „Przegląd Emigracyjny” 1 września 1892, nr 5, s. 44: „Zrobiwszy raz z robotnikiem polskim doświadczenie tak korzystne, ajencje duńskie w roku przyszłym sprowadzą większą liczbę robotników polskich"; por. A. Mүткоwicz, Powstanie i rozwój emigracji sezonowej, Kraków 1917, s. 157, autor napisał, że w 1892 r. przybyło do Danii 510 polskich robotników.

16 A. Dobrowolski, Ksiadz Edward Ortved, „Tygodnik Ilustrowany” 7 marca 1903, nr 10, s. 193-194.

17 J. Wasilkowski, Na rzecz wolnej Polski. Towarzystwo Polskie w Danii i jego poprzednicy 1973-2001, Kopenhaga 2002, s. VIII.

18 Polacy w Danji, „Kurjer Lwowski” 8 stycznia 1902, nr 8, s. 2.

19 J. Окоцошісz, Wychodźstwo i osadnictwo polskie przed wojna światowa, Warszawa 1920, s. 285-286: „Ruch wychodźczy do Danii rozpoczął się w 1893 r., zainicjowało go 400 robotników polskich z Galicji”. 
stematycznie wzrastała. Miasteczko Maribo było administracyjnym centrum wysp i jednocześnie centrum polskości w Danii.

Największa liczba robotników rolnych udających się do Danii pochodziła z Galicji, z miejscowości leżących wzdłuż linii kolejowej Kraków-Lwów. Emigranci z Galicji wywodzili się najczęściej z powiatów: brzeskiego, bocheńskiego, krakowskiego, dąbrowskiego, tarnowskiego, niskiego, tarnobrzeskiego, lwowskiego, wadowickiego, wielickiego, łańcuckiego, limanowskiego. Pozostała część pochodziła z ziem zaboru rosyjskiego, przeważnie z dawnych guberni: płockiej, kaliskiej i piotrkowskiej. Nieznaczny był procent emigrantów z zaboru pruskiego ${ }^{20}$.

Polscy robotnicy sezonowi w Danii w latach 1893-1913 spędzali około 8-9 miesięcy w ciągu roku. Wielu z nich przyjeżdżało tu na każdy sezon, wielu z nich jeszcze przed I wojną światową postanowiło pozostać na stałe. Od 1914 r. zaczęło się osadnictwo na skalę masowąą. W 1911 r. na ogólną liczbę 10320 Polaków 4609 było zatrudnionych na wyspach Lolland i Falster, 1232 w Jutlandii, a pozostali porozrzucani na pozostałych wyspach ${ }^{22}$. „Kurier Lwowski” informował na swoich łamach: „Robocza ludność polska na Szląsku i w Poznańskiem, tak zw. «obieżysasi» [...] zwróciła się teraz do Danji i coraz thumniej tam przybywa. Jestto nowy zupełnie prąd emigracyjny"23. W 1901 r. redakcja dziennika informowała o przybyciu do pracy: „w b.r. około 7000 robotników polskich”24. Jak zaznaczono: „Potrzeby religijne zaspakaja ksiądz misjonarz z Krakowa, który bywa tu dwa razy w roku”25. Z tą myślą, by zaradzić wielorakim potrzebom rodaków i: „Celem zapobieżenia wyzyskowi ludu polskiego w Danji, kilku księży w W. Ks. Poznańskiem postanowiło udać się do Danji i osiedlić się tam, aby niosąc posługę duchowną polskim rodzinom robotniczym, opiekować się zarazem niemi i bronić przed wyzyskiem. W tym celu księża ci uczą się obecnie języka polskiego"26.

Zdaniem ks. Wilhelma Szymbora ${ }^{27}$, który w Danii pełnił posługę duszpasterską, okazjonalnie odwiedzając skupiska polskie, rokrocznie przebywało tam około 18 000-20 000 Polaków ${ }^{28}$.

20 J. DYктUs, Emigracja i opieka duszpasterska nad emigrantami w diecezji krakowskiej w świetle ankiet konsystorza z 1907 i 1913 roku, „Studia Polonijne” 2(1977), s. 141-142; por. Robotnicy polscy w Danji. (Wywiad z dyr. Okołowiczem), „Kurjer Lwowski” 30 września 1910, nr 453, s. 1.

${ }^{21}$ E. OlsZewsKi, Emigracja polska w Danii 1893-1993, s. 86; W. ZDUneK, Duszpasterstwo Polaków w Danii (1893-1978), s. 146-147.

22 J. OкоєоwICZ, Wychodźstwo i osadnictwo polskie przed wojna światowa, s. 286; por. A. ZwIERCAN OFMConv, Działalność Franciszkanów wśród Polonii, „Studia Polonijne” 3(1979), s. 108-109.

${ }^{23}$ Wychodźtwo polskie w Danji, „Kurjer Lwowski” 30 lipca 1894, s. 2.

${ }^{24}$ O emigracji polskiej w Danji, „Kurjer Lwowski” 6 listopada 1901, nr 308, s. 4.

${ }_{25}$ Robotnicy polscy w Danji i Szwecji, „Kurjer Lwowski” 21 lipca 1908, nr 336, s. 1.

${ }^{26}$ Dla opieki, ,Kurjer Lwowski” 14 sierpnia 1910, nr 375, s. 3. 
Religia katolicka w Danii była przez ponad 300 lat zakazana. Wolność wszystkim religiom i wyznaniom zapewniła dopiero w 1849 r. uchwalona poprawka do duńskiej konstytucji, która usunęła zakaz królewski z 1624 r., zabraniający pod karą śmierci przebywania na terenie Królestwa Duńskiego duchownym katolickim. Jakkolwiek dla stałych misji dyplomatycznych i obcokrajowców przebywających w Danii (w Kopenhadze) oraz dla garnizonu wojskowego (we Frederici) w 1765 r. otwarto kościół katolicki św. Ansgara w Kopenhadze i w 1767 r. św. Kanuta we Frederici na Jutlandii. W latach 1650-1800 nabożeństwa dla zagranicznych katolików odprawiali przy poselstwach w Kopenhadze i w garnizonie we Frederici - jezuici. Po utworzeniu w 1868 r. prefektury apostolskiej w Danii (przemianowanej w 1892 r. w wikariat apostolski) zaczęli tu przybywać księża zakonni z sąsiednich krajów. Duchowni ci rekrutowali się głównie z Niemców, Holendrów, Belgów i Austriaków ${ }^{29}$.

Jako pierwsi od 1872 r. podjęli pracę misyjną (kościół św. Ansgara w Kopenhadze i kolegium św. Andrzeja i Aarhus na Jutlandii) jezuici z prowincji północnoniemieckiej. W 1897 r. przybyli do Danii pierwsi kamilianie (OSCam), którzy w 1901 r. otworzyli klinikę (od 1907 r. z oddziałem gruźliczym). Organizując posługę duszpasterską wybudowali kaplice w Frederikshavn (1934) i w Viborgu (1941). 9 stycznia 1899 r., w niespełna dwa lata później, przybyli do Odense redemptoryści (CSsR): o. Gaudenty Schmiderer i ks. Piotr Damian Steidl. W 1901 r. zakupili teren na Amager (Kopenhaga) i wybudowali kościół św. Anny. W 1926 r. zbudowali

${ }^{27}$ Ks. J. Szymański, Duszpasterze Polonii i Polaków za granica. Stownik biograficzny, t. I, Lublin 2010, s. 141-144.

${ }^{28}$ W. Szymbor, Wśród wychodźców naszych w Danii, „Roczniki Obydwóch Zgromadzeń Św. Wincentego a Paulo” (Kraków) 20(1914), z. 1, s. 21: „Liczbę Polaków w Danii zajętych mogłem naogół stwierdzić na podstawie urzędowych sprawozdań. Do takich należą: 1) co rok wydawane «Bertning fra Indenrigministeriet - undenlandske Arbeidere», a 2) «Directorium» dla księży. To kościelne, tamto rządowe. Jedno spisane na podstawie liczb podawanych przez księży do wikaryatu, drugie na podstawie statystyki, zbieranej przez t. zw. «Herreds-Kantory», a wysyłanej do ministerstwa spraw wewnętrznych. Otóż «Directorium» podaje na r. 1913 Polaków 14000, a «Beretning» 12000. Nie można bezwzględnie polegać na tych dwóch oficjalnych źródłach. Bezpośrednio stwierdziłem na miejscu zupełnie inne liczby: np. Aalborg według oficjalnych źródeł ma 400 Polaków, tymczasem znalazłem ich 900; Aarhus oficyalnie 500, w pastoracji miałem ich 1600, Bornholm oficyalnie 150, ja ich widziałem 500, Horsens oficyalnie 500, do mnie przyszło 800, a Kopenhadze przypisuje się 2850 katolików nie wspominając ani słówkiem o Polakach; tymczasem w rzeczywistości jest ich tu 1500 do 1700"; por. E. LateR-ChodyŁowa, Liczebność i rozmieszczenie emigracji polskiej w Danii, s. 1930; J. Szymański, Z dziejów opieki duszpasterskiej nad Polakami w Danii w 1927 r., s. 161.

${ }^{29}$ E.S. KruszewsKI, Położenie katolików w krajach skandynawskich od pierwszej połowy XVI do połowy XIX wieku. Zarys, „Rocznik Instytutu Polsko-Skandynawskiego” 3(1987/1988), s. 19-24; E. Olszewski, Emigracja polska w Danii 1893-1993, s. 86; J. Hergenröther, Historia Powszechna Kościoła katolickiego, t. XVIII i XIX, Warszawa 1905, s. 132-136; W. ZDUnEK, Duszpasterstwo Polaków w Danii (1893-1978), s. 146-147. 
kościół w Naestved, a w 1939 r. przybyli do Nykøbing Falster ${ }^{30}$. Od 1910 r. misja redemptorystów sprowadzała się do duszpasterstwa wśród emigracji polskiej ${ }^{31}$. To oni obsługiwali parafie zamieszkałe przez Polaków w: Amager, Odense, Naestved, Svendsborg, Nybørg, Assens, Vordinborg, Ronne, Aarkirkeby, a także prowadzili szkoły na Amager, w Odense, Naestved. Wśród nich był duszpasterz pochodzenia polskiego, ks. Franz Stefan Jaworski ${ }^{32}$. Początkowo spośród redemptorystów najbardziej dla Polaków zasłużył się o. Damian Steidl ${ }^{33}$. W latach 1911-1923 był on proboszczem kościoła św. Anny w Kopenhadze, do którego uczęszczali Polacy ${ }^{34}$. Od 1923 do 1936 r. pełnił funkcję proboszcza w Naesved na wyspie Zelandii, gdzie mieszkało około 900 polskich emigrantów ${ }^{35}$. W 1936 r. objął stanowisko proboszcza po ks. A. Ammerlaanie, holenderskim franciszkaninie w Nykøbing na wyspie Falster. Ksiądz D. Steidl za opiekę nad Polakami otrzymał medal od rządu austriackiego ${ }^{36}$.

Z kolei 7 czerwca 1901 r. w Roskide osiedlili się montfortanie (SMM). Biskup Jan von Euch w 1910 r. przekazał im duszpasterstwo nad Polakami na Zelandii, Bornholmie i Samso, a od 1917 r. - w Holbaek i od 1930 r. - w Taastrup. Ich dziełem są świątynie wybudowane w: Roskilde, Ringsted, Slagelse, Holbaek czy Koge.

W latach 1912-1951 działalność misyjną w południowej Jutlandii prowadzili sercanie (SCJ). Od $1907 \mathrm{r}$. istniała tu samodzielna parafia. Pierwszym proboszczem katolickim był ks. J. Hellman, następnym Ludwik Wolff (1919-1935), a w latach

${ }^{30}$ E. OlszZwwski, Emigracja polska w Danii 1893-1993, s. 87-88; J. SzYMaŃsKi, Z dziejów opieki duszpasterskiej nad Polakami w Danii w 1927 r., s. 159.

31 J. Szymaszek, Duszpasterstwo polskie w Danii, s. 169.

${ }^{32}$ Franz Stefan JAWORSKI urodził się 2 września 1888 r. w Dreźnie. W 1907 r. wstąpił do Zgromadzenia Redemptorystów. Studiował filozofię i teologię w Mautern w Austrii. Święcenia kapłańskie przyjął 27 lipca 1914 r. w Mautern. Posługę duszpasterską pełnił [w:] kościele św. Anny w Kopenhadze (1914-1930), Naestved (1930-1939), Odense (1939-1948), Nykøbing F. (1948-1950), Odense (1950-1958). Zmarł 24 czerwca 1958 r. w Naestved. E. OLSZEwsKi, Emigracja polska w Danii 18931993, s. 94, 98, 234; J. SZYMAŃSKI, Z dziejów opieki duszpasterskiej nad Polakami w Danii w 1927 r., s. 165.

${ }^{33}$ Peter Damian SteidL urodził się 23 lutego 1873 r. w Dobbiako-Toblach w Austrii. W 1898 r. przybył do Odense, był duszpasterzem w kościele św. Anny w Kopenhadze (1909-1922), potem w Naestved, Nykøbing F., od 1939 r. wizytator, a potem wiceprowincjał zakonów w Danii i Szwecji (1942-1945), członek Rady Biskupiej i Trybunału Kościelnego (1941-1946). Zmarł 14 sierpnia 1946 r. E. Olszewski, Emigracja polska w Danii 1893-1993, s. 92, 94, 385.

34 J. SzYMaszeK, Duszpasterstwo polskie w Danii, s. 169-170.

${ }_{35}$ Archiwum Archidiecezjalne w Gnieźnie [dalej: AAG], Archiwum Prymasa Polski [dalej: APP], Akta Protektora Wychodźstwa Polskiego [dalej: APWP], Dania, Dział III/63, X. Tadeusz Kotowski Rektor Misji Polskiej w Belgii, Raport ze stanu opieki religijnej nad emigracją polską w Danii, Nr 287/27; J. SzYMaŃSKI, Z dziejów opieki duszpasterskiej nad Polakami w Danii w 1927 r., s. 165.

${ }^{36}$ AAG, APP, APWP, Danja, Dział III/63, Ks. Stanisław Misiaszek, Uwagi o położeniu religijnym Polaków w Danii z dnia 22 września 1933 r. 
1935-1944 polski duchowny K.D. Jaworski (używał nazwiska Casimir Dionysius Flandrup $)^{37}$.

Emigracja polska w Danii należała do jednej z najbardziej zaniedbanych duszpastersko wychodźczych skupisk w Europie. Polacy, którzy osiedlili się na południowych wyspach duńskich - Lolland i Falster, byli tam bowiem jedynymi katolikami. Na tym terenie nie było też ani jednego kapłana katolickiego, ani kościoła czy kaplicy katolickiej. Miejscowy ordynariusz ks. biskup J. von Euch, wikariusz apostolski Danii i Islandii, po przybyciu na Lolland-Falster pierwszej grupy polskich robotnic sezonowych usiłował sprostać temu wyzwaniu, powierzając opiekę duszpasterską nad Polakami ks. Edwardowi Ortvedowi ${ }^{38}$. Duńskiego kapłana, który w niewielkim wówczas stopniu znał język polski, wezwał do powrotu z Norwegii i skierował go jeszcze w 1893 r. na Lolland ${ }^{39}$. Pierwsza msza św. została przez niego odprawiona 11 sierpnia 1893 r. w Hesteborg z udziałem 52 wiernych $^{40}$.

37 Casimir Dionysius FlandruP - (Kazimierz Dionizy Jaworski) - młodszy brat Franza Stefana. Urodził się 8 kwietnia 1901 r. w Kastrup na Amager. Studiował w Instytucie Katolickim w Paryżu. Święcenia kapłańskie przyjął 16 kwietnia 1927 r. w Paryżu. Posługę duszpasterską pełnił w kościele św. Ansgara w Kopenhadze (1927-1930 i 1933-1935), w Haderslev (1935-1944) i Fredericia (19441947), rektorem Kościoła Niepokalanego Poczęcia NMP w Kopenhadze (1947-1965 i 1967-1975), wikariuszem delegata Wikariatu Apostolskiego (1948-1953), proboszczem w Hellerup (1948-1951), generalnym wikariuszem (1953-1974). Zmarł 13 grudnia 1981 r. w Kopenhadze. E. Olszewski, Emigracja polska w Danii 1893-1993, s. 93, 98.

${ }^{38}$ Otto Edward OrTVED urodził się 3 października 1885 r. w Kopenhadze w rodzinie protestanckiej. Syn Jensa Andersena i Dorothey Christiny z d. Rasmussen. Uczęszczał do gimnazjum i na uniwersytet w rodzinnym mieście. Ukończył filologię słowiańską na wydziale filozoficznym. Przeszedł na katolicyzm. Studia teologiczne odbył w Kolegium Urbaniana przy Kongregacji Propagandy Wiary w Rzymie. 16 kwietnia 1881 r. w Bazylice św. Jana na Lateranie przyjął święcenia kapłańskie. Podjął posługę kapłańską w Wiedniu, Pradze, następnie został wikariuszem w Odense (1887), Svendborgu (1888), Kopenhadze (1889), w Norwegii w Kristiani (Oslo) był wikariuszem przy parafii św. Olafa i redagował tygodnik polityczno-religijny „Sant Olaf” (1889-1893), w sierpniu 1893 r. został wikariuszem w Frederiksburgu z zadaniem opieki nad Polakami. 25 lipca 1896 r. przeniósł się z Kopenhagi do Maribo. Z końcem marca 1905 r. został odwołany z parafii w Maribo. Odtąd był duszpasterzem w dyspozycji Wikariatu Apostolskiego. Zamieszkał w Slagelse, następnie w Herlev i Holte, ostatecznie osiadł w Orehoved, zajmował się pracą naukową. Zmarł 30 listopada 1930 r. w szpitalu św. Elżbiety w Amager. A. Dobrowolski, Ksiądz Edward Ortved, „Tygodnik Ilustrowany” 7 marca 1903 , nr 10, s. 193-194; E.S. KRuszewsKi, Pastor Edward Ortved (1855-1930), s. 27, 97, 104-117, 141-147; TENŻE, Pastor Edward Ortved (1855-1930) - opiekun Polaków w Danii, „Acta Cassubiana” 4(2002), s. 7-89; E. Olszewski, Emigracja polska w Danii 1893-1993, s. 90.

39 E.S. KRuszewski, Jak redemptorysta ,stawat w potrzebie” o. Jan Tomasz Szymaszek (19011989), „Rocznik Instytutu Polsko-Skandynawskiego” 17( 2001/2002), s. 27; TENŻE, Śladami polskiego apostolstwa w Danii, [w:] W nieustajacej trosce o polska diasporę, s. 151-164; J. SZYMASZEK, Duszpasterstwo polskie w Danii, s. 165.

${ }^{40}$ E.S. Kruszewski, Pastor Edward Ortved (1855-1930) - opiekun Polaków w Danii, s. 11. 
Praca duszpasterska sprowadzała się początkowo do elementarnych posług religijnych. Z czasem przybrała formy bardziej trwałego oddziaływania, prowadząc wraz $\mathrm{z}$ rozwojem osadnictwa stałego do kształtowania się więzów lokalnych ${ }^{41}$. Ksiądz Ortved odprawiał msze św. z kazaniami w języku polskim w Vesterborg i Maribo, a następnie odwiedzał z posługą duszpasterską około 40 miejscowości, w których pracowali Polacy ${ }^{42}$. Dzięki ks. Ortvedowi już w 1893 r. zorganizowano w Maribo, rozległą terytorialnie, parafię katolicką. Przy wydatnej finansowej pomocy polskich emigrantów wybudował tam kościół pw. św. Brygidy i św. Stanisława Biskupa. Oprócz kościoła, wybudował też polską szkołę i schronisko dla poszukujących pracy Polaków ${ }^{43}$. Proboszczem tej parafii ks. Ortwed był do marca $1905 \mathrm{r}^{44} \mathrm{Od}$ 1903 r. w posłudze duszpasterskiej pomagał mu ks. Józef Knapen, monfortanin ${ }^{45}$.

$\mathrm{Z}$ osobą ks. Ortveda związane są początki pracy polskich sióstr zakonnych w Danii. Podczas jednego z jego licznych pobytów na ziemiach polskich spotkał się w Warszawie z matką Florentyną Dymman, przełożoną Zgromadzenia Sióstr Franciszkanek Rodziny Maryi. Prosił o przysłanie kilku sióstr do pomocy w prowadzeniu parafii w Maribo i zorganizowaniu opieki nad polskimi robotnicami. Od 1900 r.

${ }^{41}$ E. Olszewski, Z problemów życia narodowego Polonii duńskiej, [w:] Polacy w Skandynawii, red. E. Olszewski, Lublin 1997, s. 111.

${ }^{42}$ Polacy w Danji. (Rozmowa wspótpracownika ,, Gazety Polskiej” z księdzem Ortvedem), „,Kurjer Lwowski" 15 lutego 1903, nr 46, s. 2; W. SzYMBor, Wśród wychodźców naszych w Danii, s. 22.

${ }^{43}$ Dania. Nowy kościót dla polskich robotników w Maribo i szkoła w Amager, „Missye Katolickie” styczeń 1898, s. 26: „Wydało mu się odpowiedniejszym zbudować kościół, do którego w każdym czasie mogliby przychodzić polscy wychodźcy, na nabożeństwo nie potrzebując jeździć aż do Kopenhagi dla słuchania mszy św. i przystępowania do św. Sakramentów jak dotychczas bywało. Otóż x. Ortved wybrał się z kwestą do Galicyi, zebrał potrzebne fundusze i zaraz zabrał się do budowy kościoła na wyspie Lolland w miejscowości Maribo, co znaczy w duńskim języku mieszkanie Maryi. W dniu Wniebowzięcia Matki Najświętszej, przeszło 400 polskich robotników w strojach i Duńczyków z okolicy przybyło do Maribo, gdyż w tym dniu Wikariusz Apostolski Danii, X. Biskup Von Euch, poświęcił nowo zbudowany kościół. Podczas mszy św. polscy robotnicy śpiewali pieśni w swoim języku. [...] Ponieważ na całej wyspie Lolland nie ma drugiego kościoła katolickiego, więc $\mathrm{z}$ tej nowej świątyni polskich robotników będą korzystali także Duńczycy. [...] W parę dni później 22 sierpnia, X. Biskup von Euch poświecił drugi dom Boży - tym razem kapliczkę św. Anny w miejscowości Amager. Około 100 robotników katolików pracujących w hucie szklanej w Kastrup, musiało dotychczas chodzić do kościoła św. Angara w Kopenhadze, odległego o dwie godziny drogi [...] Odtąd będą mieli w pobliżu Kastrupu w Amager swoją kapliczkę, przy której znajduje się parę pokoików na szkołę i mieszkanie nauczyciela”. Por. R. GoścıŃski, Wśród Polonii duńskiej, „Kurjer Poznański” 2 kwietnia 1932, nr 150, s. 2.

${ }_{44}$ J. Окоцоwicz, Wychodźstwo i osadnictwo polskie przed wojna światowa, s. 285; J. SzyмASZEK, Duszpasterstwo polskie w Danii, s. 168.

${ }^{45}$ W. Zdunek, Duszpasterstwo Polaków w Danii (1893-1978), s. 165. Zmarł w 1913 r. (w 37 roku życia). 
siostry franciszkanki opiekowały się kościołem, uczyły religii, śpiewu kościelnego, pisania, czytania po polsku i robót ręcznych, pośredniczyły w korespondencji z krajem, pomagały w rozwiązywaniu konfliktów między robotnikami a pracodawcami. Placówka w Maribo została jednak zlikwidowana w roku 1907. W latach 1907-1911 w domu przebywali polscy franciszkanie, potem został sprzedany ${ }^{46}$.

Parafia katolicka była jedynym ośrodkiem umożliwiającym na terenie Danii utrzymywanie lokalnych kontaktów między Polakami: „Każda niedziela i święto były okazją nie tylko do spotkania rodaków, ale przede wszystkim do zademonstrowania w obcym kulturowo środowisku wartości narodowo-katolickich, częstokroć nieakceptowanych również przez obcych narodowościowo duszpasterzy"47.

$\mathrm{Na}$ wyspie Fionii i Langelandzie od 1906 r. wraz z ks. E. Ortvedem posługę duszpasterską sprawował o. Henryk Deutscher ${ }^{48}$, pochodzący ze Śląska, który dobrze mówił po polsku. Przez swą życzliwość i troskę o polskich robotników rolnych zdobył ich uznanie i szacunek ${ }^{49}$. W 1927 r. ks. Deutscher był proboszczem w kościele św. Anny w Kopenhadze ${ }^{50}$. Funkcję tę pełnił do 1932 r. Później, aż do wybuchu II wojny światowej był proboszczem w kościele św. Albana w Odense. Oprócz czynności liturgicznych, ks. Henryk uczył śpiewu polskich pieśni religijnych, urządzał jasełka i pomagał w przygotowaniu uroczystości o charakterze religijno-narodowym. Poza tym z polskimi nabożeństwami i kazaniami dojeżdżał do Aarhus, Horsens, Nybørg, Svendborg, Rudkjobing i Bromolla w Szwecji ${ }^{51}$.

${ }^{46}$ E. Olszewski, Emigracja polska w Danii 1893-1993, s. 91; E.S. Kruszewski, Śladami polskiego apostolstwa w Danii, [w:] W nieustajacej trosce o polska diaspore, s. 155-156.

47 AAG, APP, APWP, Danja, Dział III/63, X. Tadeusz Kotowski Rektor Misji Polskiej w Belgii, Raport ze stanu opieki religijnej nad emigracją polską w Danii, Nr 287/27; J. SzYMAŃsKi, Z dziejów opieki duszpasterskiej nad Polakami w Danii w 1927 r., s. 155; E. Olszzewski, Polska Misja Katolicka w Danii i jej duszpasterze - organizatorzy, [w:] Duchowieństwo polskie w świecie. Materiaty VII Międzynarodowego Sympozjum Biografistyki Polonijnej. Papieski Uniwersytet Urbaniański. Rzym, 17-18 października 2002 r., red. A. i Z. Judyccy, Torun 2002, s. 244.

${ }^{48}$ AAG, APP, APWP, Danja, Dział III/63, Ks. Stanisław Janicki, Sprawozdanie z odwiedzin placówek duszpasterskich dla Polaków z dnia 11 grudnia 1930; E.S. KRuszewski, Śladami polskiego apostolstwa w Danii, [w:] W nieustającej trosce o polska diasporę, s. 160.

Henryk Deutscher urodził się w 1882 r., w swojej pracy duszpasterskiej w latach 1910-1939 opiekował się Polakami, a z czasem miał ich jako swoich parafian zwłaszcza w Odense. W stosunkach z Polakami używał w mowie i piśmie imienia „Henryk”. Zmarł 14 czerwca 1957 r. w Naestved.

49 J. SzYMASZEK, Duszpasterstwo polskie w Danii, s. 170.

${ }^{50}$ AAG, APP, APWP, Dania, Dział III/63, X. Tadeusz Kotowski Rektor Misji Polskiej w Belgii, Raport ze stanu opieki religijnej nad emigracją polską w Danii, Nr 287/27; J. SzYMAŃsKi, $Z$ dziejów opieki duszpasterskiej nad Polakami w Danii w 1927 r., s. 165.

${ }^{51}$ AAG, APP, APWP, Danja, Dział III/63, Ks. Stanisław Janicki, Sprawozdanie z odwiedzin placówek duszpasterskich dla Polaków z dnia 11 grudnia 1930; ks. J. SzYMAŃsKi, Opieka duszpasterska nad Polakami w Szwecji, „Studia Polonijne” 29(2008), s. 56. 
Po odejściu ks. E. Ortveda, do pracy duszpasterskiej włączył się kolejny redemptorysta, o. Józef Dutscke ${ }^{52}$, a po zakończeniu I wojny światowej dołączył pochodzący ze Śląska, również redemptorysta, o. Tomasz $\mathrm{Fritz}^{53}$. Z kolei po odejściu ks. D. Steidla z Naestved obowiązki proboszcza do 1939 r. sprawował ks. Resch. Ten duchowny był jednak bardzo nieprzychylnie nastawiony do polskich wychodźców. W pracy duszpasterskiej pomagał mu ks. T. Fritz, który z kolei był zaprzeczeniem swojego przełożonego w traktowaniu Polaków. Co niedzielę odprawiał dla nich mszę św., nieszpory oraz głosił kazanie po polsku. Poza tym raz w miesiącu pełnił posługę duszpasterską w małych koloniach polskich: Vordinborg, Istelingen, Stensbyggard i Rosenfeld. W katolickiej szkole prowadził katechezę w języku polskim oraz uczył mowy polskiej dzieci i młodzież emigrantów. Pomagał on w przygotowywaniu oraz brał czynny udział we wszystkich uroczystościach religijnych i narodowych. Zawsze był życzliwie nastawiony wobec księży przyjeżdżających z Polski. Za swą postawę służenia Bogu i Polsce 11 listopada 1938 r. ks. Tomasz Fritz został odznaczony przez polskie władze srebrnym krzyżem zasługi. W 1939 r. został proboszczem w Naestved.

Sprawa opieki duszpasterskiej była już stałym punktem odniesienia we wzajemnych relacjach Prymasa Polski i Ministerstwa Wyznań Religijnych i Oświecenia Publicznego ${ }^{54}$. Ksiądz prymas w odpowiedzi na zapytanie ze strony ministerstwa deklarował wprost, że: „uregulowanie duszpasterstwa wśród wychodźstwa polskiego w Danji uważa za konieczne i sprawę będzie miał na oku", jakkolwiek w podejmowanych działaniach asekurował się pewnymi trudnościami wynikającymi z braku funduszy ${ }^{55}$.

Kolejną próbą utworzenia stałej opieki duszpasterskiej nad Polakami było sprowadzenie do pracy duszpasterskiej w Danii zakonników polskich. Zgromadzeniem tym, które podjęło pracę wśród wychodźstwa polskiego w Danii, byli franciszkanie ${ }^{56}$. Na prośbę wikariusza apostolskiego w Danii biskupa Jana van Eucha, w 1907 r. prowincjał franciszkanów konwentualnych ze Lwowa, o. Peregryn Haczela, wysłał tam swoich podwładnych. Ofiarowano im na ten cel kościół

${ }^{52}$ W. Szymbor, Wśród wychodźców naszych w Danii, s. 23.

${ }^{53}$ Thomas Fritz urodził się 12 września 1893 r. w Kochlowicach w Polsce. Studiował filozofię i teologię w Mautern w Austrii. Od 1922 r. był duszpasterzem w Danii (Naestved, Kopenhaga, Nykøbing F.). Zmarł 18 lutego 1953 r. w Roskilde. E. Olszewski, Emigracja polska w Danii 1893 1993, s. 385.

${ }^{54}$ AAG, APP, APWP, Danja, Dział III/63, Do Jego Eminencji Kardynała E. Dalbora Arcybiskupa Gnieźnieńsko-Poznańskiego, Ministerstwo Wyznań Religijnych i Oświecenia Publicznego, Warszawa, 1 września $1922 \mathrm{r}$.

${ }^{55}$ AAG, APP, APWP, Danja, Dział III/63, Do Ministerstwa Wyznań Religijnych i Oświecenia Publicznego w Warszawie, ad. 5658/22.

${ }^{56}$ E.S. KRUSZEwsKi, Jak redemptorysta „stawat w potrzebie” o. Jan Tomasz Szymaszek (19011989), s. 27. 
w Maribo, zbudowany ze składek Polaków, dom mieszkalny z ogrodem i fundusze na utrzymanie zakonników. W 1907 r. przybyli tam dwaj księża i jeden zakonnik z Prowincji Galicyjskiej Franciszkanów Konwentualnych: o. Kalikst Figura, później o. Euzebiusz Pelc i brat Michał Czyż. 18 czerwca 1907 r. Kongregacja Rozkrzewiania Wiary zatwierdziła placówkę misyjną w Maribo, zmieniając ją na klasztor Prowincji Galicyjskiej. Najdłużej, bo do 1912 r., pracował tam o. Tadeusz Wołczański ${ }^{57}$.

Już jednak w 1909 r. franciszkanie konwentualni z prowincji holendersko-belgijskiej zajęli miejsce polskich franciszkanów i przejęli konwent w Maribo. Swoją pracą duszpasterską obejmowali wyspy Lolland i Falster, na których zamieszkiwało od 4 do 5 tys. polskich emigrantów i tylko 125 duńskich katolików ${ }^{58}$.

Wśród franciszkanów w pracy duszpasterskiej wyróżnił się o. Cyryl Klessens ${ }^{59}$, przełożony konwentu w Maribo. W latach 1909-1911 przebywał w Małopolsce. Swoją parafię w Maribo zorganizował na wzór parafii polskiej. Istniała przy niej szkoła i internat prowadzony przez siostry ze Zgromadzenia św. Józefa z Chambery. Założył także muzeum polskiej emigracji w Danii ${ }^{60}$. Dużo czasu poświęcał pracy społecznej. Ojciec Cyryl sprawował patronat nad polskimi obchodami świąt i uroczystościami narodowo-religijnymi. W swojej parafii zorganizował i kierował Towarzystwem Serca Jezusowego, które liczyło 200 osób ${ }^{61}$.

Za opiekę nad Polakami i zasługi położone dla sprawy polskiej w Danii o. Klessens w 1927 r. otrzymał z rąk ambasadora Polski w Danii Konstantego Rozwa-

57 Z. Gogola OFMConv, Praca franciszkanów polskich wśród Polonii na przełomie XIX/XX, do 1939 roku, „Przegląd Kalwaryjski” 13(2009), s. 192; por. A. ZwIERCAN, Działalność Franciszkanów wśród Polonii, s. 109; J.D., Robotnicy polscy w Danji. (Wywiad z dyr. Okołowiczem), „Kurjer Lwowski” 30 września 1910, nr 453, s. 2.

${ }^{58}$ A. Zwiercan, Działalność Franciszkanów wśród Polonii, s. 109; Z. Gogola, Praca franciszkanów polskich wśród Polonii, s. 193.

59 Jakub Piotr KLESSENS (Cyryl) - holenderski franciszkanin konwentualny. Urodził się 24 marca 1881 r. w Rotterdamie. Studiował filozofię i teologię w Leuven w Belgii i w Rzymie. W Leuven był duszpasterzem od 18 stycznia 1907 r., a następnie od 1909 r. przebywał w Małopolsce, zapoznając się z językiem i kulturą polską. W 1911 r. organizował życie parafialne w głównych skupiskach polskich na wyspach Lolland i Falster, następnie został proboszczem w kościele św. Brygidy w Maribo (19221949). Był organizatorem Muzeum Polskiego w Maribo (otwarte 3 maja 1929 r.). Za zasługi dla polskości i katolicyzmu został odznaczony krzyżem Polonia Restituta w 1927 r. Zmarł 1 stycznia 1949 r. w Maribo. E. Olszewski, Związek Polaków - katolików w Danii (1918-1919), „Studia Polonijne” 14(1992), s. 117; Z. Gogola, Praca franciszkanów polskich wśród Polonii, s. 192-193.

${ }^{60}$ AAG, APP, APWP, Danja, Dział III/62, ks. Kotowski Tadeusz, Raport ze stanu opieki religijnej i kulturalno-oświatowej nad emigracją polską w Danii z dnia 21 stycznia 1927 r.; J. SzYmaŃsKI, Z dziejów opieki duszpasterskiej nad Polakami w Danii w 1927 r., s. 165.

${ }^{61}$ AAG, APP, APWP, Danja, Dział III/63, S. Lisoń, Raport z wizytacji placówek duszpasterskich zamieszkałych przez Polaków w Danii z dnia 15 maja 1931. 
dowskiego Order Polonia Restituta ${ }^{62}$. Po 1930 r. postawa ks. C. Klessensa wobec polskich wychodźców uległa radykalnej zmianie. Mianowicie włączył się do propagowania ruchu asymilacyjnego i był jego czołową postacią. Jako działacz tego ruchu konsekwentnie zwalczał wszystko co polskie ${ }^{63}$.

Również w parafii Nakskov, gdzie liczba Polaków wynosiła około 2 tys. osób, posługę duszpasterską spełniali holenderscy franciszkanie. W 1913 r. wybudowano tam kaplicę. Po I wojnie światowej, w 1921 r. dzięki ofiarności polskich wychodźców zbudowano tam kościół pw. św. Franciszka z Asyżu ${ }^{64}$. Proboszczem i opiekunem Polaków był ks. A. Smitz, mówiący po polsku. Nastawienie tegoż duszpasterza wobec polskich emigrantów było wrogie. Konsekwentnie dążył do „zduńczenia” Polaków ${ }^{65}$. Po nim proboszczem został jego rodak, o. Janssens, który postępował podobnie jak poprzednik ${ }^{66}$.

Holenderscy franciszkanie administrowali także parafią w Nykøbing na wyspie Falster, w której mieszkało około 1400 osób polskiego pochodzenia. Ze składek polskich wychodźców w 1916 r. wybudowano kościół pw. Podwyższenia Krzyża Świętego. Dalszej jego rozbudowy dokonano w 1927 r. ${ }^{67} \mathrm{~W}$ każdą niedzielę dla Polaków była odprawiana msza św. z kazaniem po polsku. Kontrowersyjnym wydarzeniem w tej parafii był tzw. „strajk” kościelny, który trwał od 1932 do 1936 r. Zrodził się on na tle nieporozumień polskich emigrantów z miejscowym proboszczem o. A. Ammerlaanem. Jego powodem było utrudnianie i uniemożliwianie przez ks. proboszcza wykonywania posługi duszpasterskiej w języku polskim dwom franciszkanom z Polski - o. R. Gościńskiemu i o. H. Czyżowi.

Ksiądz Ammerlaan zabronił bowiem dzieciom robotników polskich nauki religii w języku polskim oraz uroczystego przyjęcia I Komunii św. Wyprosił on z koś-

${ }^{62}$ AAG, APP, APWP, Dania, Dział III/63, Poseł Rzeczypospolitej Konstanty Rozwadowski, Eminencjo, Kopenhaga 15. III. 27r.; A. ZwIERCAN, Działalność Franciszkanów wśród Polonii, s. 111; Jubileusz pasterza wychodźców polskich w Danii, „Głos Seminarium Zagranicznego” 1935, nr 4, s. 33-34.

${ }^{63}$ Z. Gogola OFMConv, Dzieje franciszkańskiej Prowincji św. Antoniego i bł. Jakuba Strzemię 1918-1939, Kraków 2011, s. 352.

${ }^{64}$ Z. Gogola, Dzieje franciszkańskiej Prowincji, s. 351; TENŻe, Praca franciszkanów polskich wśród Polonii, s. 193; J. BAKalarz, Dania, Duszpasterstwo polonijne, [w:] Encyklopedia Katolicka, t. III, Lublin 1973, kol. 997-998.

${ }^{65}$ AAG, APP, APWP, Dania, Dział III/63, X. Tadeusz Kotowski Rektor Misji Polskiej w Belgii, Raport ze stanu opieki religijnej nad emigracją polską w Danii, Nr 287/27; Z. GoGola, Dzieje franciszkańskiej Prowincji, s. 353; J. SzYMaŃsKi, Z dziejów opieki duszpasterskiej nad Polakami w Danii w 1927 r., s. 165.

${ }^{66}$ AAG, APP, APWP, Danja, Dział III/63, Ks. Janicki Stanisław, Sprawozdanie z odwiedzin placówek duszpasterskich dla Polaków z dnia 11 grudnia 1930 r.

67 Z. Gogola, Dzieje franciszkańskiej Prowincji, s. 351. 
cioła polskich harcerzy, a ambony używał do ubliżania Polakom. Stąd też Polacy z Nykøbing zaprotestowali przeciwko takiemu traktowaniu i jeździli na mszę św. do Maribo i Naestved. Dopiero po zmianie proboszcza, kiedy na miejsce ks. Ammerlaana przyszedł znany z życzliwości dla Polaków redemptorysta o. D. Steidl, zaprzestano strajku ${ }^{68}$.

Należy dodać, że postawa franciszkanów konwentualnych z belgijsko-holenderskiej prowincji od początku była nieprzychylna wobec duszpasterzy polskich pracujących w Danii. Można sądzić, że przyczyną tego nastawienia była chęć zdominowania całokształtu pracy duszpasterskiej wśród Polaków w Danii ${ }^{69}$.

Przed wybuchem wojny światowej pojawiła się nadzieja na zorganizowanie polskiego ośrodka duszpasterskiego w Kopenhadze. W grudniu 1911 r. ks. Piotr D. Steidl odprawił na Amager pierwszą mszę św. z kazaniem w języku polskim. W tym samym roku hrabina Przeździecka rozpoczęła starania o sprowadzenie do Danii polskiego kapłana. Po wielu zabiegach przybył do Kopenhagi w grudniu 1912 r. ks. dr Walery Szymański ${ }^{70}$, były sekretarz kurii biskupiej wileńskiej ${ }^{71}$. Jeszcze przed jego przyjazdem $\mathrm{w}$ pomieszczeniach zlikwidowanego szpitala przy Bredgade urządzono kaplicę katolicką, rezydencję dla księdza i salę dla wiernych. Przy aktywnej pomocy Polaków zamieszkałych w Kopenhadze utworzył polską bibliotekę, zorganizował nauczanie języka polskiego i religii, otoczył opieką bezdomnych i biednych emigrantów. Ze względu na zły stan zdrowia wiosną 1914 r. opuścił jednak Danię i wyjechał do Belgii ${ }^{72}$. Nie zorganizował też polskiego duszpasterstwa jezuita ks. Feliks Wierciński, przybyły w 1912 r. do Aarhus na Jutlandii ${ }^{73}$.

Swój udział w posłudze duszpasterskiej nad Polakami w Danii mieli również montfortaniści, zwani też grignonistami ${ }^{74}$, pochodzący z Holandii. Centrum ich po-

${ }^{68}$ AAG, APP, APWP, Danja, Dział III/63, Misje w Danii. ks. Misiaszek Stanisław, Uwagi o położeniu religijnym Polaków w Danii z dnia 22 września 1933 r.; S. Kościelecka, Dzieje Polonii w Danii w latach 1892-1940, s. 97.

${ }^{69}$ S. Kościelecka, Dzieje Polonii w Danii w latach 1892-1940, s. 95.

${ }^{70}$ Zmiany w duchowieństwie, „Dwutygodnik Dyecezjalny Wileński” 10 lipca 1911, nr 13, s. 170.

71 E.S. KRuszewsKi, Jak redemptorysta ,stawat w potrzebie” o. Jan Tomasz Szymaszek (19011989), s. 27-28.

72 AAG, APP, APWP, Danja, Dział III/63, Misje w Danii, ks. Stanisław Misiaszek, Uwagi o położeniu religijnym Polaków w Danii z dnia 22 września 1933 r.; E.S. KRUSzewski, Śladami polskiego apostolstwa w Danii, [w:] W nieustającej trosce o polska diasporę, s. 157; W. ZDUNEK, Duszpasterstwo Polaków w Danii (1893-1978), s. 167.

73 E. OLszewsKi, Emigracja polska w Danii 1893-1993, s. 94.

${ }^{74}$ Montfortaniści, grignoniści - duchowni ze zgromadzenia misjonarzy Towarzystwo Maryi założonego w 1722 r. przez św. Ludwika Marię Grignona de Montfort, w: Podręczna Encyklopedia Kościelna, t. XIII-XIV, Warszawa 1907, s. 341. 
sługi duszpasterskiej była wyspa Zelandia. W parafii Slagelse, gdzie żyło około 195 polskich rodzin, proboszczem był o. Hoppers, mówiący po polsku. W niedzielę odprawiał dla Polaków mszę św. i głosił kazanie w języku polskim, a po mszy św. uczył polskich pieśni religijnych. Poza tym w każdą ostatnią niedzielę miesiąca dojeżdżał z posługą duszpasterską do Koge oraz co roku głosił kazanie w języku polskim na uroczystość Bożego Ciała w Roskilde. Podobnie i w Ringsted większość parafian stanowili Polacy (około 300 osób). Proboszczem był o. Boerrigter, niemówiący po polsku, który współpracował z polskimi organizacjami. Co półtora miesiąca z polskimi nabożeństwami dojeżdżał tu ks. T. Fritz z Naestved. W szkole parafialnej katechizacji w języku polskim udzielała s. Józefa ze Zgromadzenia Sióstr św. Jadwigi z Wrocławia. Uczyła ona także języka polskiego.

Około 100 polskich wychodźców było w parafii Roskilde, którą zarządzali o. Quadolieg ${ }^{75}$ i o. Mariboe, nieznający języka polskiego. W Kjoge przebywało około 300 Polaków. Proboszczem był o. Kartenraad, również nieznający języka polskiego $^{76}$.

Jutlandia z kolei była terenem pracy duszpasterskiej księży jezuitów. Swoją postawą kapłańską zdobyli uznanie i szacunek polskich emigrantów. Nie włączyli się w ruch asymilacyjny przeciwko Polakom prowadzony przez księży obcokrajowców w Danii. Ojciec Lenkov, który dobrze mówił po polsku, służył pomocą i opieką duszpasterską około 500 Polakom w parafii Pindstrup ${ }^{77}$. Natomiast dla Polaków w parafii Aarhus, gdzie mieszkało około 50 polskich rodzin, posługę duszpasterską spełniał o. P. Wunscher ${ }^{78}$. Największą katolicką parafią w Danii było Haderslev. Zamieszkiwało tam około 700 rodzin polskich. Opiekę nad nimi roztaczał przyjaciel Polaków, o. Ludwik Volff. Nie zgadzał się on z asymilacją innych narodowości i stawał w opozycji do niepolskich księży, zwolenników tego ruchu. Współpracował z polskimi organizacjami i Poselstwem Polskim w Kopenhadze. Założył i kierował Katolickim Towarzystwem Młodzieży, które liczyło 36 osób ${ }^{79}$.

Ponadto wychodźcy polscy zamieszkiwali na Jutlandii w parafiach: Kolding, Aalborg, Horsens, Eysber. Proboszczem w Kolding był przyjaciel Polaków, ks. Jakub E. Olrik ${ }^{80}$, mówiący dobrze po polsku. Katechizacji w katolickiej szkole udzie-

75 J. SzYMaŃSKI, Z dziejów opieki duszpasterskiej nad Polakami w Danii w 1927 r., s. 165.

${ }^{76}$ AAG, APP, APWP, Danja, Dział III/63, Ks. Stanisław Janicki, Sprawozdanie z odwiedzin placówek duszpasterskich dla Polaków z dnia 11 grudnia 1930 r.

${ }^{77}$ AAG, APP, APWP, Danja, Dział III/63, O. W. Konopka, Kancelaria Prymasa Polski /Raport z Danii z dnia 5 września 1932/. Katolicy w Danii.

${ }^{78}$ AAG, APP, APWP, Danja, Dział III/63, Ks. Stanisław Janicki, Sprawozdanie z odwiedzin placówek duszpasterskich dla Polaków z dnia 11 grudnia 1930 r.

79 Tamże.

${ }^{80}$ Zmarł w 1959 r. 
lały siostry św. Jadwigi z Wrocławia. One także opiekowały się chorymi w katolickim szpitalu w tejże miejscowości. Parafia ta liczyła około 30 polskich rodzin.

W Horsens, gdzie było około 40 polskich rodzin, opiekę duszpasterską pełnił ks. Schreiber, nieumiejący mówić po polsku.

W Eysber, gdzie była mała polska kolonia, z posługą kapłańską dojeżdżał z Vejle o. Optikul, norbertanin.

W Aalborgu nieliczną grupę polskich emigrantów otaczał gorliwą i troskliwą opieką duszpasterską o. Bender, niemiecki kamilianin ${ }^{81}$.

Na wyspie Zelandii parafia Nivaa liczyła około 300 osób polskiego pochodzenia. Stanowili oni większość parafian. Duszpasterzem był o. Flynn, irlandzki lazarysta.

Dużą pomoc w pracy duszpasterskiej niosły siostry zakonne mówiące po polsku. One to w katolickich szkołach prowadziły katechizację w języku polskim, uczyły dzieci i młodzież języka polskiego, prowadziły ochronki dla dzieci polskich, a także opiekowały się chorymi Polakami. Szczególne zasługi miały siostry ze Zgromadzenia św. Jadwigi z Wrocławia i św. Józefa z Chambery ${ }^{82}$.

Jak zauważył E. Olszewski, polskie organizacje społeczno-zawodowe, przy poparciu Poselstwa Polskiego, instytucji kościelnych, nauczycieli czyniły wielokrotnie starania o utworzenie Polskiej Misji Katolickiej w Danii, bądź obsadzenia parafii, w których większość stanowili Polacy, przez polskich kapłanów. Wysyłały szereg petycji i interweniowały u prymasa Polski kardynała Augusta Hlonda, prosząc o przysłanie polskich księży do opieki duszpasterskiej ${ }^{83}$.

O trosce w sprawie polskich wychodźców w Danii świadczy list rektora Polskiej Misji Katolickiej [dalej: PMK] w Belgii ks. Tadeusza Kotowskiego, skierowany do prymasa Polski, w którym wskazywał, iż:

Ze względu na to, że od czternastu przeszło lat, Emigracja Polska w Danji nie miała odwiedzin księdza-Polaka, a ostatnio w polskiej prasie emigracyjnej ${ }^{84}$ często odzywa-

${ }^{81}$ AAG, APP, APWP, Dania, Dział III/63, X. Tadeusz Kotowski Rektor Misji Polskiej w Belgii, Raport ze stanu opieki religijnej nad emigracją polską w Danii, Nr 287/27; J. SzYMAŃsKi, Z dziejów opieki duszpasterskiej nad Polakami w Danii w 1927 r., s. 165.

82 W. Zdunek, Duszpasterstwo Polaków w Danii (1893-1978), s. 168-170.

${ }^{83}$ E. OlsZewski, Polska Misja katolicka w Danii i jej duszpasterze - organizatorzy, s. 245; J. SzymaŃsKi, Zwiazek Robotników Polskich w Danii, s. 165-178; S. KoścIeleCKa, Dzieje Polonii w Danii w latach 1892-1940, s. 98; Jak żyją wychodźcy polscy w Danji. Pierwsze posiedzenie Rady Naczelnej Związku Robotników Polskich w Danji, „Narodowiec” 8 lutego 1928.

${ }^{84}$ Danja jest tylko terenem emigracji sezonowej, „Narodowiec” 26 czerwca 1926; Wychodztwo polskie w Danji, „Narodowiec” 27 czerwca 1926; S.D., Wychodztwo polskie w Danji, „Narodowiec” 30 czerwca 1926; I. KąDZIOŁA, Z życia robotników polskich w Danji, „Narodowiec” 20 lipca 1926; R.K., Z wychodztwa polskiego w Danji, „Narodowiec” 7 sierpnia 1926; R.K., Z wychodztwa polskiego w Danji, „Narodowiec” 10 sierpnia 1926, nr 183; R.K., Uroczystość św. Ansgara. - Udziat wychodzców, 
ły się głosy, że pod względem opieki duszpasterskiej o trzynastu tysiącach naszych rodaków w Danji zupełnie zapomniano w Kraju - w porozumieniu z Posłem Polskim w Kopenhadze i Wikariuszem Apostolskim w Danji, Księdzem Biskupem Bremsem bezpośrednio po świętach Bożego Narodzenia, wyjechałem na dwutygodniowy objazd Misyjny po Danji. Po powrocie do Brukseli mam zaszczyt przesłać na ręce Waszej Eminencji szczegółowy raport z objazdu Misyjnego, gorąco polecając Jego dostojnej opiece nasze wychodźtwo w Danji. Do raporu załączam: Mapkę katolickiej Danji z oznaczeniem parafji, gdzie zamieszkują Polacy; Zeszyt z wycinkami z gazet; Paczkę fotografji, które dają pojęcie o charakterze i typie ludności polskiej w Danji ${ }^{85}$.

Zainteresowanie rektora wypływało też m.in. z publikacji prasowych, które jednoznacznie podnosiły problem opieki duszpasterskiej nad Polakami ${ }^{86}$. Stąd też kardynał A. Hlond 22 lutego 1927 r. w piśmie skierowanym do posła RP w Kopenhadze, Konstantego Rozwadowskiego, informował, że zamierza wysłać do Danii na stałe do duszpasterstwa na razie jednego księdza, który by się osiedlił w Kopenhadze i stworzył tam, jak we Francji i w Belgii, centrum Polskiej Misji Katolickiej. W odpowiedzi ambasador Rozwadowski napisał: „Postanowienie Waszej Eminencji wysłania na stałe do Danji polskiego kapłana dla zorganizowania Polskiej Misji Katolickiej, spełnia najważniejszy punkt programu pracy Poselstwa nad emigracją polską, a zarazem urzeczywistnia jej najgorętsze życzenia" - sugerując jednocześnie, ,by wybór waszej Eminencji co do polskiego kapłana dla Danji, padł na osobę o zbliżonych do ks. Kotowskiego kwalifikacjach" ${ }^{87}$. Uprzedzając działania prymasa Polski, rektor PMK w Belgii, ks. Tadeusz Kotowski, zwrócił się do prymasa A. Hlonda z prośbą o rozszerzenie działalności misji w Belgii na Holandię i Danię.

\footnotetext{
„Narodowiec” 13 sierpnia 1926; Duchowieństwo katolickie wynaradawia Polaków - czy nie można im posłać księży polskich, „Narodowiec” 17 sierpnia 1926; Trzeba zgodnie i świadomie dązyć do celu: zachowania polskości, „Narodowiec” 15 sierpnia 1926; Zadania Związu Robotników na najbliższa przyszłość, „Narodowiec” 18 sierpnia 1926; R.K., Z wychodztwa polskiego w Danji, „Narodowiec” 25 sierpnia 1926; Harcerze polscy wracają do Danji, „Narodowiec” 29 sierpnia 1926; A. PoDGóRskI, Z wychodztwa polskiego w Danji, Obchód ,C Cudu nad Wista”" w Koge, ,, Narodowiec” 2 września 1926; W. RudNik, Co polski harcerz z Danji widziat w Polsce?, „Narodowiec” 24 września 1926; Nie damy sobie wydrzeć ani ducha polskiego ani polskiej mowy, „Narodowiec” 27 września 1926; Jak żyje wychodztwo polskie w Danji, „Narodowiec” 27 listopada 1926; Danja, „Narodowiec” 12 grudnia 1926; Ks. J.P. KLesSEns, Do moich Rodaków koło Maribo w Danji, z kolenda, „Narodowiec” 18 grudnia 1926.

${ }^{85}$ AAG, APP, APWP, Dania, Dział III/63, X. Tadeusz Kotowski Rektor Misji Polskiej w Belgii, Eminencjo, Najdostojniejszy Księże Prymasie, Bruxelles, le 21 stycznia 1927.

${ }^{86}$ Wychodźcy polscy w Danji domagaja się od rządu polskiego polskich nauczycieli i księży, „Narodowiec” 27 stycznia 1927; Powrót polskich robotnic sezonowych z Danji do kraju, „Narodowiec" 16 stycznia 1927.

${ }^{87}$ AAG, APP, APWP, Dania, Dział III/63, Poseł Rzeczypospolitej Konstanty Rozwadowski, Eminencjo, Kopenhaga 15. III. 27 r.
} 
„De facto - napisał - sprawami duszpasterstwa w tych dwóch krajach Polska Misja Katolicka zajmowała się od chwili jej powołania"s8.

Licząc na pozytywne rozwiązania, w piśmie do Kancelarii Prymasa Polski ks. Kotowski napisał:

jeżeli weźmiemy pod uwagę, że na 13 tys. Polaków w Danjii jest [14] kilkunastu księży, wprawdzie cudzoziemców, ale mówiących po polsku ${ }^{90}$, sprawa wysłania księdza do Danji wydaje mi się mniej pilna niż obsadzenie bodaj dwóch kapelanji w Belgji, zwłaszcza, że praca księdza Polaka w Danji nie tyleby miała charakter duszpasterski, ile raczej ksiądz Polak spełniałby rolę czynnika koordynującego i pośredniczącego pomiędzy Wikarjatem Apostolskim a naszymi Władzami. Stanowisko wyjątkowo trudne i wymagające wyjątkowych kwalifikacji ${ }^{91}$.

Zapewne w odpowiedzi na powyższe uwagi i na prośbę Poselstwa Polskiego w Hadze i Konsulatu w Amsterdamie prymas Polski 10 kwietnia 1927 r. rozszerzył kompetencję Polskiej Misji Katolickiej w Belgii również na Holandię i Danię. Z jego polecenia i w porozumieniu z Ministerstwem Spraw Zagranicznych i Urzędem Emigracyjnym w Warszawie, rektor PMK w Belgii, ks. T. Kotowski, miał „zapoznać się na miejscu z potrzebami religijnymi naszego wychodźstwa w tych krajach, odwiedzić ks. ks. Biskupów Holandii i Danii i w porozumieniu z nimi oraz z naszymi Poselstwami w Hadze i Kopenhadze przystąpić do organizacji opieki religijnej”92.

${ }^{88}$ AAG, APP, APWP, Belgia - Generalia, Dział II, Vol I/44a, Ks. Tadeusz Kotowski Rektor PMK w Belgji, Do Jego Eminencji Najdostojniejszego Księdza Metropolity Gnieźnieńsko-Poznańskiego Prymasa Polski, Poznań, Nr 317/27; ks. J. SzYmaŃski, Obraz duszpasterstwa polskojęzycznego w Europie na podstawie wizytacji rektora Polskiej Misji Katolickiej w Belgii, „Archiwa, Biblioteki i Muzea Kościelne" 97(2012), s. 342.

${ }^{89}$ Emigracja polska w Danji, „Biuletyn Katolików Polskich w Belgji, Danji i Holandji” 8/12(1927), s. 5-6.

${ }^{90}$ Duszpasterze Ci w okresie poprzedzającym swój pobyt w Danii przebywali na terenie Galicji i poznali język polski. Dzięki staraniom przedstawicieli Austro-Węgier w Kopenhadze sprowadzono ich do Danii i powierzono im opiekę duszpasterską nad Polakami. Z chwilą klęski militarnej państw centralnych i odrodzenia się państwa polskiego, dążyli oni do asymilacji wychodźstwa polskiego poprzez propagowanie niewiary w trwałość państwa polskiego, przedstawiali sytuację społeczno-polityczną w Polsce bardzo negatywnie. Poza środkami propagandowymi, organizacyjnie dążyli do rozbicia Związków Polaków Katolików w Danii. Zob. S. Wiтkowski, „Polak w Danii” 1918-1919, „Kwartalnik Historii Prasy Polskiej” 25(1986), z. 3, s. 47-56.

${ }^{91}$ AAG, APP, APWP, Belgia - Generalia, Dział II, Vol I/44a, Ks. Tadeusz Kotowski Rektor P.M.K. w Belgji, Przewielebny Ksiądz Prałat Zborowski, Kancelarja Prymasa Polski, Poznań, Bruksela, 24 lutego 1927.

${ }_{92}$ Opieka religijna nad Polakami w Holandji i Danji, „Biuletyn Komitetu Opieki Kulturalno-Społecznej dla Wychodztwa Polskiego w Belgji” czerwiec 1927, s. 3; Emigracja polska w Danji, „Biuletyn Katolików Polskich w Belgji, Danji i Holandji” 8/12(1927), s. 5-6. 
Sprawa zorganizowania stałej opieki religijno-kulturalnej w Holandii i Danii była omawiana też 29 kwietnia 1927 r. w Warszawie, podczas posiedzenia międzyministerialnej Komisji Opieki nad Polakami Zagranicą ${ }^{93}$.

W powyższej sprawie, w związku z podjętymi działaniami, rektor otrzymał pisma „od X. Wikariusza Apostolskiego i Posła polskiego w Kopenhadze, z których wynika[ło], że wszelka opieka duszpasterska kapłanów polskich zależnych od J. Em. Kardynała Prymasa Polski napotyka na niezwykły opór szowinistycznie usposobionych Misjonarzy z pochodzenia przeważnie Holendrów i Niemców. Poseł polski w Kopenhadze ${ }^{94}$ przewid[ywał] nawet konieczność interweniowania u Stolicy Św. Sprawę na miejscu zbadam i po powrocie nadeślę wyczerpujące raporty ze stanu opieki duszpasterskiej w Holandii i Danii”"95.

Zapowiedziany raport, będący wizją lokalną w miejscu pobytu wychodźców polskich w Danii, przyniósł surową ocenę zaistniałej sytuacji. W punkcie I wspomnianego raportu rektor napisal:

Stosunek ks. Wikariusza Apostolskiego w Kopenhadze i kleru do sprawy zorganizowania polskiej opieki religijnej w Danji [...] Początkowo X. Wikarjusz Apostolski przyjął inicjatywę J. Em. Ks. Kardynała Polski z całą życzliwością, lecz po niejakim czasie sytuacja uległa zasadniczej zmianie.

W początkach lipca b.r. na konferencji zwołanej przez X. Wikarjusza Apostolskiego do Nestved w Zelandji w sprawie organizacji szkolnictwa katolickiego w Danji - grupa Misjonarzy władających językiem polskim, składająca się z księży narodowości niemieckiej i holenderskiej w liczbie 15 wystąiła ze stanowczym protestem przeciw jakiejbądźkolwiek ingerencji Episkopatu i kleru polskiego do spraw duszpasterstwa w Danji.

Żeby należycie zrozumieć takie stanowisko kleru - pisał dalej rektor - należy nadmienić, że ostatnio w katolickich kołach misyjnych w Danji zarysowała się wyraźnie chęć nadania akcji misyjnej charakteru wyłącznie duńskiego. Wobec tego, że na ogólną liczbę 25 tysięcy katolików w Danji jest około 13 tysięcy Polaków i 5 tysięcy Niemców - kler pragnie przeprowadzić forsowną asymilację, podkreślając, że o ile nie da się zduńczyć Polaków i Niemców - Misja Katolicka w Danji będzie miała zawsze dla Duńczyków charakter obcy.

${ }_{93}$ Opieka kulturalna nad emigracja polska w Belgji, ,Biuletyn Komitetu Opieki Kulturalno-Społecznej dla Wychodztwa Polskiego w Belgji” czerwiec 1927, s. 2-3. Komisja ta pracowała od września 1923 r., i w jej skład wchodzili przedstawiciele Ministerstwa Spraw Zagranicznych, Urzędu Emigracyjnego, Ministerstwa Oświaty, Ministerstwa Spraw Wewnętrznych.

${ }_{94}$ Posłami RP w Kopenhadze byli: Aleksander Dzieduszycki (13 X 1919-1 I 1924); Kazimierz Papee (1 I 1924-24 X 1924); Konstanty Rozwadowski (24 X 1924-1 VIII 1928). Zob. Rocznik Stużby Zagranicznej Rzeczypospolitej Polskiej wedlug stanu na 1 kwietnia 1938, Warszawa 1938, s. 57.

${ }^{95}$ AAG, APP, APWP, Belgia - Generalia, Dział III, Vol I/44a, Ks. Tadeusz Kotowski Rektor P.M.K. w Brukseli, Kancelarja J.E.X. Kardynała Prymasa Polski, Wydział Opieki nad Polakami Zagranicą, Poznań, Bruxelles, le 2 sierpnia 1927. 
Ksiądz Kotowski argumentację tę powtórzył również w punkcie VI przywołanego raportu: Dążność kół kościelnych do zasymilowania emigracji polskiej, wykazując, że: „Postępy katolicyzmu wśród Duńczyków są znikome, wpływy Misjonarzy na społeczeństwo, mniej lub więcej oświecone - prawie żadne. Pozostaje jedyne wyjście - jak najszybciej zasymilować Polaków. W ten sposób uzyska się poważną podstawę do dalszej pracy misyjnej" ${ }^{96}$.

W kolejnym raporcie, by temu zapobiec, sugerował dokonanie podziału parafii na trzy grupy: 1 - parafie, gdzie Polacy stanowili 90\% wiernych; 2 - parafie, gdzie Polacy stanowili 50\% wiernych i 3 - pozostałe. W pierwszej grupie parafii Polacy powinni mieć nabożeństwa w każdą niedzielę i święta, a dzieci katechizację w języku polskim; w drugiej - 2 razy w miesiącu i w uroczystości obchodzone przez katolików, również z katechizacją w języku polskim; natomiast w trzeciej - nabożeństwa odbywałyby się parę razy do roku, w zależności od możliwości sprowadzenia księdza mówiącego w języku polskim ${ }^{97}$.

W jednym z następnych pism wskazywał, że: „Sprawa opieki religijnej w Danii jest niesłychanie skomplikowana, ze względu na zasadniczą politykę kościelną Wikariatu Apostolskiego, popieraną w pewnej mierze przez Kongregację Propagandy, zmierzającej do wynarodowienia naszej emigracji”"98. Przy tym rektor skarżył się w piśmie do Kurii Prymasowskiej na „brak instrukcji z Poznania w sprawie zasadniczego ustosunkowania się Kurii Prymasowskiej do asymilacyjnej polityki kół kościelnych w Danji" ${ }^{99}$, i z przykrością konstatował swoje uwagi w raporcie do ks. prymasa Augusta Hlonda: „,...] niestety, opiekę duchowną nad Polakami zagranicą sprawują Holendrzy, Niemcy, Francuzi, Belgowie - Polaków i Polek prawie najzupełniej brak. Jest to dla nas nie tylko bolesne, ale i upokarzające"100. Niemniej, starał się łagodzić nastroje społeczne wiernych, rozwiązywać ujawniające się konflikty, prezesowi ZPK w Danii pisał wprost: „Musimy cierpliwie i spokojnie

96 AAG, APP, APWP, Danja, Dział III/63, Raport ze stanu opieki religijnej i kulturalno-społecznej nad emigracją polską w Danji, Opracowany po jednomiesięcznym pobycie w Danji od 13-go sierpnia do 13-go września 1927 r. Rektora Polskiej Misji Katolickiej w Brukseli.

${ }^{97}$ AAG, APP, APWP, Dania, Dział III/63, Ks. Tadeusz Kotowski Rektor PMK na Belgję, Danję i Holandję, Do Kancelarji Jego Eminencji Księdza Kardynała Polski, Bruxelles, le 4 kwietnia 1928; zob. S. Kościelecka, Dzieje Polonii w Danii w latach 1892-1940, s. 95.

98 AAG, APP, APWP, Belgia - Generalia, Dział III, Vol I/44a, Ks. T. Kotowski Rektor P.M.K. na Belgję, Danję i Holandję, Najdostojniejsza Kurja Poznańska, Wydział Opieki nad Polakami Zagranicą, Bruxelles, le 6 października 1927.

99 AAG, APP, APWP, Belgia - Generalia, Dział II, Vol I/44a, Sprawozdanie z działalności Polskiej Misji Katolickiej w Brukselii od 1/IX do 31/XII 1927 r., Bruksela, 20 lutego 1928 r., s. 1-2.

100 AAG, APP, APWP, Dania, Dział III/63, X. Tadeusz Kotowski Rektor Misji Polskiej w Belgii, Raport ze stanu opieki religijnej nad emigracją polską w Danii, Nr 287/27; J. SzYMAŃsKi, Z dziejów opieki duszpasterskiej nad Polakami w Danii, s. 167. 
odczekać instrukcji, jakie stamtąd otrzymamy [Kancelaria Prymasowska] Proszę rodaków naszych uspokoić i zapewnić, że ks. kard. Prymas i Rząd polski szczerze zajęli się waszą sprawą"101.

Jako rektor PMK ks. Kotowski podczas swoich objazdów misyjnych w Danii przeprowadził trzytygodniowe misje; dokonał czterech objazdów; brał udział w jedenastu zebraniach; wygłosił 9 odczytów oraz zorganizował, podczas czternastu wykładów, kurs dla sióstr zakonnych z nauki języka i literatury polskiej oraz nauki o Polsce współczesnej ${ }^{102}$. W czasie tych wizyt przeciwko jego osobie uruchomiono cały aparat intryg, który w ostateczności uniemożliwił dalsze jego przyjazdy ${ }^{103}$.

W okresie wakacyjnym o możliwość pracy duszpasterskiej zabiegał ks. Piotr Augustynik ${ }^{104}$, który w piśmie do Kurii Biskupiej w Częstochowie prosił o możliwość wakacyjnego wyjazdu, ,aby prowadzić pracę duszpasterską, pomiędzy robotnikami polskimi [...] - jak argumentował - o tyle łatwiej dla mnie, że znam dosyć dobrze język duński i szwedzki"105. Z tą samą prośbą zwrócił się do prymasa Polski, od którego oczekiwał delegacji, co ciekawe, w swoim piśmie ponownie zastrzegł, ,że zna język duński i szwedzki”'106. W podróż misyjną został delegowany przez kardynała Augusta Hlonda i po swym przyjeździe zobowiązany do złożenia sprawozdania prymasowi Polski o sytuacji emigracji polskiej ${ }^{107}$. Niemniej - jak zauważył ambasador Polski w Danii - „z polecenia proboszczów nie był nigdzie wpuszczony do Kościoła"108.

101 AAG, APP, APWP, Dania, Dział III/63, Rektor PMK na Belgję, Danję i Holandję, Do Pana prezesa Kożucha w Nykøbing, Bruxelles, le 26 października 1927.

102 AAG, APP, APWP, Belgia - Generalia, Dział III, Vol I/44a, Ks. T. Kotowski Rektor P.M.K. w Brukseli, Sprawozdanie z działalności Polskiej Misji Katolickiej w Brukseli za kwartał od 1-go czerwca do 1-go września 1927 r.

${ }^{103}$ AAG, APP, APWP, Dania, Dział III/63, Konstanty Rozwadowski Poseł Rzeczypospolitej w Danji, Eminencjo, Kopenhaga dn. 26 listopada 1927 r.; Z. Gogola, Dzieje franciszkańskiej Prowincji, s. 352.

${ }^{104}$ Archiwum Archidiecezjalne w Częstochowie [dalej: AACz], Akta personalne ks. Piotra Augustynika, sygn. AP 2. Curriculum vitae, sac. Petrus Augustynik. Ks. Piotr Augustynik w miesiącach wakacyjnych w 1927 r. odbył podróż do Danii i Szwecji, gdzie prowadził pracę duszpasterską wśród polskich robotników przybyłych tam do pracy sezonowej.

${ }^{105}$ AACz, Akta personalne ks. Piotra Augustynika, sygn. AP 2, Do Prześwietnej Kurii Biskupiej, Wieluń, 15 lutego 1927.

${ }^{106}$ AAG, APP, APWP, Danja, Dział III/63, Ks. Piotr Augustynik, Do Jego Ekscelencji Najprzewielebniejszego Księdza Biskupa Prymasa w Poznaniu, Wieluń, 1 marca 1927 r.

107 AAG, APP, APWP, Szwecja, Dział III/109, Pismo do ks. Piotra Augustynika z Kancelarii Prymasa Polski z dnia 26 kwietnia 1927.

${ }^{108}$ AAG, APP, APWP, Dania, Dział III/63, Konstanty Rozwadowski Poseł Rzeczypospolitej w Danji, Eminencjo, Kopenhaga dn. 26 listopada 1927 r. 
W listopadzie 1929 r. przybył do Danii przyboczny sekretarz prymasa Polski ks. dr Stanisław Janicki ${ }^{109}$, w celu zbadania położenia Polaków w Danii, i - jak sam to określił - przygotowania gruntu dla duszpasterzy polskich w Danii. Samo zachowanie ks. Janickiego wywołało ogromne rozgoryczenie i głęboki żal u rodaków spodziewających się po przedstawicielu ks. prymasa załagodzenia narastających konfliktów ${ }^{110}$. Zapewne pozyskane wówczas przez ks. prymasa informacje stanowiły podstawę do zwrócenia się z prośbą do prowincjała oo. redemptorystów w Krakowie o pomoc w organizacji opieki duszpasterskiej nad Polakami w Danii ${ }^{111}$. Lakoniczna odpowiedź ze strony prowincjała pozostała bez wpływu na oczekiwanie ks. prymasa ${ }^{112}$

W następnym roku, na Wielkanoc Związek Robotników Polskich w Danii zwrócił się do prymasa Polski o delegowanie do Danii, dla obsługi Polaków w czasie wielkanocnym, kapłana z Polski ${ }^{113}$. Z tym zadaniem przybył do Danii i usiłował się zmierzyć ks. prof. Stanisław Lisoń ${ }^{114}$. Jego przyjazd był zupełnie nieprzygotowany, Kancelaria Prymasowska nie poinformowała nawet o tym zarządu ZRP w Danii.

109 Stanisław JANICKI - kapłan archidiecezji poznańskiej. Urodził się 26 kwietnia 1894 r. w Buku. W 1916 r. po ukończeniu Arcybiskupiego Seminarium Duchownego w Poznaniu otrzymał święcenia kapłańskie. Od 1918 r. studiował w Münster. Następnie był wikariuszem: w Swarzędzu, Rydzynie, a od 1919 prefektem w Poznaniu. Studiował historię Kościoła na Uniwersytecie Warszawskim i w Rzymie, gdzie w 1926 r. uzyskał doktorat. W latach 1927-1929 wykładał w polskim seminarium duchownym w Orchard Lake (USA). Od 1929 r. pełnił obowiązki referenta ds. emigracji Przybocznej Kancelarii Prymasa i wykładowcy seminarium duchownego w Poznaniu. W 1936 r. został proboszczem w Środzie Wielkopolskiej. 6 stycznia 1940 r. został zamordowany przez Niemców w Forcie VII. J. BAZYDıo, Janicki Stanisław, [w:] Encyklopedia Katolicka, t. VII, Lublin 1997, kol. 963; E. OLSZEWSKI, Emigracja polska, s. 147, 228-229, 233.

110 J. SZYMAŃSKI, Związek Robotników Polskich w Danii, s. 169.

111 AAG, APP, APWP, Dania, Dział III/63, Do Przewiel. o. Prowincjała Emanuela Trzemeskiego OO. Redemptorystów w Krakowie, Podgórze, Poznań dn. 8 stycznia 1929 r.

112 AAG, APP, APWP, Dania, Dział III/63, Odpis. O. Emanuel Trzemeski CSSR, Prowincjał Redemptorystów w Krakowie, 18 stycznia 1929 r. „W Danji pracują nasi Ojcowie prowincji wiedeńskiej na trzech placówkach i mają Ojców mówiących po polsku, którzy wyłącznie poświęcają się bardzo gorliwie duszpasterstwu nad Polakami. W Odense pracuje O. Henryk Deutscher, mówi bardzo dobrze po polsku - w Kopenhadze jest O. Franciszek Jaworski, Polak - w Nastwed pracuje O. Józef Dutschke. Każdy z nich ma wyznaczony rejon szczególnie wiosek i folwarków, w których przebywają Polacy i mogę zaświadczyć, że rzeczywiście z całym poświęceniem spełniają swoje zadania".

113 J. SZYMAŃsKi, Związek Robotników Polskich w Danii, s. 170.

114 Stanisław Kostka Lisoń - kapłan archidiecezji poznańskiej. Urodził się 21 października 1881 r. w Jarocinie. Syn Dionizego i Julianny z d. Jerzycka. Uczęszczał do szkoły elementarnej w Jarocinie, a od 1897 r. do gimnazjum w Poznaniu. W 1901 r. przeniósł się do Gimnazjum Ostrowskiego, gdzie 21 marca 1905 uzyskał świadectwo dojrzałości. Po odbyciu studiów filozoficzno-teologicznych w Arcybiskupim Seminarium Duchownym w Poznaniu i Gnieźnie 14 lutego 1909 r. przyjął święcenia kapłańskie. Od 1 marca pełnił obowiązki wikariusza w Międzyrzeczu, a od 1 stycznia 1914 w Rogoźnie, 
W tymże samym roku, z ramienia Polskiego Towarzystwa Emigracyjnego przebywał w Danii ksiądz diecezji warszawskiej Stanisław Starkiewicz. W Nykøbing na wyspie Falster pełnił posługę duszpasterską wśród rodaków, odwiedzał polskie rodziny. Jego posługa kapłańska nie była uzgodniona wcześniej z miejscowym duchowieństwem. $Z$ tego to powodu do kancelarii prymasowskiej napłynęło na niego wiele skarg od miejscowych proboszczów oraz od wikariusza apostolskiego, biskupa J. Bremsa ${ }^{115}$.

W zaistniałej sytuacji kardynał Hlond poprosił prowincjała franciszkanów, o. Kornelego Czupryka, o obsadzenie jednej z placówek duszpasterskich w Danii. Definitorium prowincjalne na sesji w dniu 5 września 1931 r. podjęło decyzję przyjęcia parafii w Nykøbing, ustanawiając przełożonym placówki i wikariuszem parafii o. Rajnera Gościńskiego. Po świętach Bożego Narodzenia w 1931 r. o. Gościński ${ }^{116}$ wyjechał do Nykøbing, gdzie po nauczeniu się języka duńskiego miał przejąć administrację parafii obsługiwanej w tym czasie przez franciszkanów z Holandii ${ }^{115}$.

gdzie pełnił jednocześnie funkcję prefekta gimnazjum. Był też członkiem magistratu w tym mieście. 1 listopada 1927 został ojcem duchownym w Arcybiskupim Seminarium Duchownym w Poznaniu. Podczas wakacji angażował się w posługę duszpasterską wśród wychodźstwa polskiego. Był dyrektorem diecezjalnym Unii Apostolskiej Kapłanów i członkiem Bractwa Księży Misjonarzy „Dobrego Pasterza”. W Sądzie Metropolitalnym w Poznaniu pełnił funkcję obrońcy węzła małżeńskiego. Zmarł 24 marca 1937 r. Pochowany został na cmentarzu św. Marcina w Poznaniu. H. Kubera, Ks. Stanisław Lisoń. Wspomnienie (1881-1937), „Gazeta Wyborcza” (Poznań) 15 stycznia 2004, s. 14.

115 AAG, APP, APWP, Danja, Dział III/63, Uwagi o stosunkach religijnych wśród Polonii duńskiej. W sprawie stosunku duchowieństwa katolickiego w Danii do emigracji polskiej. Z kancelarii Prymasa Polski (20 grudnia 1930 r.).

${ }^{116}$ Ludwik Rajner GoścıŃsKi - kapłan Zakonu Braci Mniejszych Franciszkanów Konwentualnych. Urodził się 19 grudnia 1890 r. w Krościenku Niżnym k. Krosna, syn Józefa. W 1909 r. wstąpił do Zakonu Braci Mniejszych Franciszkanów Konwentualnych (przyjął imię Rajner). Od listopada 1912 r. studiował na Uniwersytecie Gregoriańskim w Rzymie, a następnie we Fryburgu (Szwajcaria). Latem 1915 r. powrócił do Krakowa, gdzie kontynuował studia seminaryjne. 12 maja 1918 r. przyjął święcenia kapłańskie. Uzyskał doktorat z filozofii. Od maja 1918 r. podjął obowiązki duszpasterskie w Warszawie, od 1923 r. w Poznaniu, a następnie we Lwowie, gdzie od 1927 r. był sekretarzem polskiej prowincji zakonnej franciszkanów. W 1931 r. został mianowany wizytatorem apostolskim Zgromadzenia Sióstr Niepokalanek. Od 2 stycznia 1932 r. do lutego 1933 był duszpasterzem Polaków w Danii, zamieszkiwał w Nykøbing (wyspa Falster). Po powrocie do Polski został przełożonym klasztoru franciszkańskiego i kościoła w Kaliszu. 7 listopada 1934 r. sekularyzował się. Zamieszkał w Warszawie. Od stycznia 1935 do września 1939 r. pracował jako kierownik biura w Stowarzyszeniu Uczestników Walki o Szkołę Polską. W czasie okupacji działał w konspiracji. Od 1 października 1944 r. był członkiem Polskiej Partii Robotniczej; delegatem na I Zjazd PPR - jako członek egzekutywy z Komitetu Powiatowego PPR Krosno. W latach 1944-1945 i 1947-1948 był wicestarostą krośnieńskim. W tym okresie pracował jako instruktor propagandy w KC PPR. 26 kwietnia 1946 zosta posłem do KRN. W latach 1948-1950 był prezydentem Przemyśla. Od 1960 r. pracował jako instruktor KP PZPR w Krośnie, a od 1961 jako instruktor Wojewódzkiego Ośrodka Propagandy Partyjnej 
Zrozumiałe, że po tak zaciętej walce o księdza Polaka, z tutejszym duchowieństwem katolickim, tylu latach starań, oczekiwań, przybycie ks. rodaka sprawiło ogromną radość wśród Polaków. We wszystkich koloniach polskich oczekiwano na przyjazdy polskiego kapłana. Nowy duszpasterz przez tutejszych księży proboszczów, jak i ks. biskupa Bremsa w Kopenhadze nie został jednak dopuszczony prawie do żadnego kościoła $\mathrm{z}$ nabożeństwem dla Polaków ${ }^{118}$. Niemniej praca duszpasterska o. Rajnera przyczyniła się do podniesienia poziomu życia moralnego i religijnego rodaków. Wobec wrogiej postawy ks. A. Smitza, po rocznym pobycie - 3 lutego 1933 r. opuścił on Danię. Na jego miejsce przyjechał polski kapłan z tego samego zgromadzenia, o. Hugolin Czyż ${ }^{119}$, który był współpracownikiem ks. proboszcza Ammerlaana. I podobnie jak w odniesieniu do jego poprzednika, wrogie stanowisko ks. proboszcza zmusiło go do wyjazdu z Danii ${ }^{120}$. W takiej sytuacji trudno było sprostać prymasowi Polski życzeniu organizatorów II Zlotu Młodzieży Polskiej do Danii, który miał miejsce w Meribo, w Zielone Święta, o delegowanie kapłana z Polski. I tym razem księdza Polaka nie oddelegowano do posługi duszpa-

w Rzeszowie. Zaangażował się w akcję odczytową propagującą ateizm. Został odznaczony m.in. Złotym Krzyżem Zasługi. W 1968 r. przeszedł na emeryturę. Zmarł 31 lipca 1969 r. w Rzeszowie i tam został pochowany. J.R. BAR OFMConv, Gościński Rajner Ludwik (1890-1969), [w:] Stownik polskich pisarzy franciszkańskich (Bernardyni i Franciszkanie ślascy, Franciszkanie Konwentualni, Klaryski oraz Zgromadzenia III Reguły), red. H.E. Wyczawski, Warszawa 1981, s. 151-152; K. STECKo, Gościński Ludwik, [w:] Słownik biograficzny działaczy polskiego ruchu robotniczego, red. F. Tych [i in.], t. II, Warszawa 1987, s. 321; E. OLszewsKi, Emigracja polska, s. 173, 177, 179, 181, 230-231, 580; J. SzymańsKi, Związek Robotników Polskich w Danii, s. 173-174; A. Zwiercan, Działalność Franciszkanów wśród Polonii, s. 112

117 Z. Gogola, Praca franciszkanów polskich wśród Polonii, s. 193; S. Kościelecka, Dzieje Polonii w Danii w latach 1892-1940, s. 96.

118 „Ks. R. Gościński został umieszczony w Nykøbing na wyspie Falster, jako wikary u ks. proboszcza, jednego z najzacieklejszych przeciwników polskości. Wiedzieć trzeba, że tutejsi księża mają jeden wspólny front - nie dopuścić polskich księży do Danii, co im się udało w r. 1927 z ks. dr. Tadeuszem Kotowskim". Zob. W. Kożuch, Polacy w Danii. Obca opieka duszpasterska a ojczysta nad Polakami w Danii, „Robotnik” - dodatek do „Gazety Grudziądzkiej” 9 sierpnia 1933; por. E. KoŁoDZIEJ, Wychodźstwo zarobkowe z Polski 1918-1939. Studia nad polityka emigracyjną II Rzeczypospolitej, Warszawa 1982, s. 119.

119 Hugolin Franciszek Czyż (1893-1976) - franciszkanin konw. Urodził się 3 grudnia 1893 r. w Trześniowie k. Jasła. Do zakonu wstąpił w 1909 r., wieczystą profesję zakonną złożył 25 grudnia 1913 r. Studia filozoficzne odbył w Uniwersytecie Gregoriańskim w Rzymie, teologiczne w Krakowie w seminarium zakonnym, święcenia kapłańskie przyjął 12 maja 1918 r. Jako kapłan pracował w wielu klasztorach, najdłużej w Wilnie (1921-1926 i 1934-1936), Kalwarii Pacławskiej (1926-1933), Krakowie (1940-1961) i Jaśle (1961-1976). Był gwardianem w Wilnie, Kalwarii Pacławskiej i w Gdyni. Zmarł w Jaśle 28 czerwca 1976 r. J.R. BAR OFMConv, Czyż Hugolin Franciszek (1893-1976), [w:] Stownik polskich pisarzy franciszkańskich, s. 97.

120 E. OlszewsKi, Emigracja polska w Danii 1893-1993, s. 231. 
sterskiej $^{121}$. Za to na zaproszenie miejscowych duszpasterzy, którzy za żadną cenę nie wpuścili do kościoła o. R. Gościńskiego, na święta wielkanocne przybył o. Stanisław Misiaszek, redemptorysta z Krakowa ${ }^{122}$, który przez sześć miesięcy pełnił posługę duszpasterską w różnych ośrodkach polskich. Po sześciu miesiącach jednak i on musiał opuścić wychodźców polskich ${ }^{123}$. Po nim obowiązki duszpasterskie w Nykøbing podjął o. Krzysztof Górecki, polski franciszkanin. Był on ostatnim polskim kapłanem skierowanym do pracy duszpasterskiej wśród Polonii duńskiej. Ciągłe kłótnie, nieporozumienia z proboszczem o. Ammerlaanem były przyczyną i jego wyjazdu 5 października 1935 r. ${ }^{124}$

Dwukrotnie Polaków w Danii odwiedzili polscy biskupi. W 1907 r., przed przybyciem polskich franciszkanów ze Lwowa, kolonie polskie wizytował biskup Józef Bilczewski ${ }^{125}$. W 1932 r., z okazji Kongresu Eucharystycznego w Kopenhadze odbyło się specjalne spotkanie kardynała A. Hlonda z Polonią duńską ${ }^{126}$.

121 J. SZYMaŃSKI, Związek Robotników Polskich w Danii, s. 173.

122 Stanisław MisiaSzeK - kapłan Zgromadzenia Najświętszego Odkupiciela (redemptorysta). Urodził się 18 listopada 1899 r. w Mędrzychowie. Pierwszą profesję złożył 2 sierpnia 1918. Święcenia kapłańskie przyjął 28 czerwca 1925 r. z rąk biskupa Edwarda Komara w Tuchowie. W latach 19261927 był misjonarzem w Kościanie, Mościskach (1927-1929), Warszawie (1929-1930), ponownie w Mościskach. Od 1931 r. był socjuszem dyrektora małego seminarium w Toruniu, a następnie pracował jako misjonarz w Krakowie (1932-1934) i Zamościu (1934-1935). W tym czasie jako misjonarz podejmował posługę duszpasterską wśród wychodźstwa polskiego w Danii, m.in. od Wielkanocy 1934 r. przez 6 miesięcy duszpasterzował w Nykøbing. W 1935 r. podjął posługę duszpasterską wśród Polaków w Brazylii. Był duszpasterzem w Treze de Maio. W 1938 r. podjął posługę duszpasterską wśród Polaków i Indian w Argentynie. Był duszpasterzem w Rosario, Las Lomitas, Villa Angela i Posadas. W 1960 r. uczył języka polskiego i literatury polskiej w Wyższym Instytucie Nauczycielskim w Posadas oraz dogmatyki w tamtejszym Seminarium Katechetycznym. Od 1962 r. pełnił obowiązki duszpasterskie w General Pinedo. Wydawał czasopisma: „Centinela” (1948-1954) i „El Faro” (19571960). Zmarł 17 lipca 1970 r. w Charata. M. Brudzisz, Misiaszek Stanisław, [w:] Stownik polskich teologów katolickich 1918-1981, red. L. Grzebień SJ, t. VI, Warszawa 1983, s. 493-496; A. OwCZARSKI CSsR, Bibliografia redemptorystów polskich (1883-2008), Kraków 2009, s. 144-146; A.H. WróBEL OFM, Historia duszpasterstwa polskiego w Argentynie w latach 1897-1997, Buenos Aires 2002, s. 330; J. Pitoń CM, Księża polscy w Brazylii 1848-1984, [w:] Zmagania polonijne w Brazylii, t. IV: Owocująca przeszłość, red. T. Dworecki SVD, Warszawa 1987, s. 109; E. Olszowski, Emigracja polska, s. 231; Z.A. JudYCKI, Polscy duchowni w świecie. Stownik biograficzny, Kielce 2008, s. 268.

${ }^{123}$ E. Olszewski, Emigracja polska w Danii 1893-1993, s. 231; J. SzYMaszeK, Duszpasterstwo polskie w Danii, s. 171.

124 E. Olszewski, Emigracja polska w Danii 1893-1993, s. 231; J. SzYMaszeK, Duszpasterstwo polskie w Danii, s. 170.

${ }^{125}$ E.S. KruSzewSKI, Śladami polskiego apostolstwa w Danii, [w:] W nieustającej trosce o polska diasporę, s. 156.

126 R. GościŃski, Prymas Polski wśród Polonii duńskiej, „Kurjer Poznański” 25 sierpnia 1932, nr 386, s. 5; W. ZduneK, Duszpasterstwo Polaków w Danii (1893-1978), s. 167. 
Emigracja polska w Danii nie miała zapewnionej odpowiedniej opieki religijnej. W posłudze religijnej i duchowej dla polskiej emigracji księża napotykali wiele trudności. Jedną z nich było wielkie rozproszenie Polaków. Ujemny wpływ na uczęszczanie do kościoła powodowały zbyt duże odległości (od 5 do $50 \mathrm{~km}$ ). Również całodzienna praca utrudniała, a nawet uniemożliwiała korzystanie z posługi duszpasterskiej. Poza tym brak było dostatecznej liczby polskich księży. Z osobą księdza polskiego emigrant również wiązał nadzieje o charakterze społecznym. Potrzebował księdza jako obrońcy, doradcy, nauczyciela i powiernika duchowego. Tymczasem rolę tę pełnili duchowni pochodzenia holenderskiego, niemieckiego, belgijskiego, którzy nigdy nie rozumieli psychiki polskiego wychodźcy. Księża ci z niechęcią odnosili się do działalności organizacyjnej Polaków w Danii. Stanowisko miejscowego duchowieństwa wobec księży z Polski nacechowane było niechęcią i dążnością do uniemożliwienia im wykonywania posług duszpasterskich ${ }^{127}$. Nieliczni proboszczowie, jak ks. Wolff z Haderslev, ks. H. Deutscher z Odense, ks. Bender z Aalborgu, rozumieli Polaków i współpracowali z polskimi organizacjami w Danii ${ }^{128}$.

Niemniej Związek Polaków w Danii nigdy nie zaprzestał starań o obsadzenie polonijnych parafii przez zakonników. W końcu lat trzydziestych wysunął projekt minimum: powierzenie jednej parafii polskim franciszkanom. W tej sprawie w czerwcu 1939 r. do biskupa Kopenhagi udał się prowincjał o. Anzelm Kubit. Niestety, wybuch II wojny światowej położył kres wszelkim planom, które miały na celu rozwiązanie problemu polskiego duszpasterstwa w Danii ${ }^{129}$. Oddolna inicjatywa rodaków jednoczących się przeciwko obcym narodowościowo duszpasterzom pozostawała „niemym krzykiem” ${ }^{30}$.

\section{BIBLIOGRAFIA}

\section{Źródla archiwalne}

Archiwum Archidiecezjalne w Gnieźnie, Archiwum Prymasa Polski, Akta Protektora Wychodźstwa Polskiego,

Belgia - Generalia, Dział II, Vol I/44a.

Dania, Dział III/62.

Dania, Dział III/63.

Szwecja, Dział III/109.

127 E. OlsZEwSKI, Emigracja polska w Danii 1893-1993, s. 231.

${ }^{128}$ AAG, APP, APWP, Dania, Dział III/63, Rektor PMK na Belgję, Danję i Holandję, Do Pana prezesa Kożucha w Nykøbing, Bruxelles, le 26 października 1927.

129 Z. Gogola, Dzieje franciszkańskiej Prowincji, s. 355; A. ZwiErcan, Działalność Franciszkanów wśród Polonii, s. 112;

130 J. SzYMAŃsKi, Z dziejów opieki duszpasterskiej nad Polakami w Danii, s. 166-167. 
Archiwum Archidiecezjalne w Częstochowie, Akta personalne ks. Piotra Augustynika, sygn. AP 2. Curriculum vitae, sac. Petrus Augustynik.

\section{Opracowania}

BaKalarz J., Dania. Duszpasterstwo polonijne, [w:] Encyklopedia Katolicka, t. III, Lublin: TN KUL 1973.

BAR J.R. OFMConv, Czyż Hugolin Franciszek (1893-1976), [w:] Słownik polskich pisarzy franciszkańskich (Bernardyni i Franciszkanie śląscy, Franciszkanie Konwentualni, Klaryski oraz Zgromadzenia III Reguły), red. H.E. Wyczawski, Warszawa: Archiwum Prowincji OO. Bernardynów 1981.

BAR J.R. OFMConv, Gościński Rajner Ludwik (1890-1969), [w:] Słownik polskich pisarzy franciszkańskich (Bernardyni i Franciszkanie śląscy, Franciszkanie Konwentualni, Klaryski oraz Zgromadzenia III Reguły), red. H.E. Wyczawski, Warszawa: Archiwum Prowincji OO. Bernardynów 1981.

BAZYDŁo J., Janicki Stanisław, [w:] Encyklopedia Katolicka, t. VII, Lublin: TN KUL 1997, kol. 963.

BrudzISz M., Misiaszek Stanisław, [w:] Słownik polskich teologów katolickich 19181981, red. L. Grzebień SJ, t. VI, Warszawa: ATK 1983.

ChoJnacki W., Stan i potrzeby badań nad Polonią duńską, „Przegląd Zachodni” 1977, nr 5/6, s. 131-134.

Chojnacki W., Materiały do bibliografii Polonii duńskiej, „Przegląd Zachodni” 1974, nr 2, s. $340-361$.

D.J., Robotnicy polscy w Danji. (Wywiad z dyr. Okołowiczem), „Kurjer Lwowski” 30 września 1910, nr 453, s. 2.

D.S., Wychodztwo polskie w Danji, „Narodowiec” 30 czerwca 1926.

Dania. Nowy kościół dla polskich robotników w Maribo i szkoła w Amager, „Missye Katolickie" styczeń 1898.

Danja, „Narodowiec” 12 grudnia 1926.

Danja jest tylko terenem emigracji sezonowej, „Narodowiec” 26 czerwca 1926.

Dla opieki, „Kurjer Lwowski” 14 sierpnia 1910.

Dobrowolski A., Ksiądz Edward Ortved, ,Tygodnik Ilustrowany” 7 marca 1903, nr 10.

Duchowieństwo katolickie wynaradawia Polaków - czy nie można im posłać księży polskich, „Narodowiec” 17 sierpnia 1926.

Dyktus J., Emigracja i opieka duszpasterska nad emigrantami w diecezji krakowskiej w świetle ankiet konsystorza z 1907 i 1913 roku, „Studia Polonijne” 2(1977).

Emigracja polska w Danji, „Biuletyn Katolików Polskich w Belgji, Danji i Holandji” 8/12(1927).

Gogola Z. OFMConv, Dzieje franciszkańskiej Prowincji św. Antoniego i bł. Jakuba Strzemię 1918-1939, Kraków: UNUM 2011.

Gogola Z. OFMConv, Praca franciszkanów polskich wśród Polonii na przełomie XIX/XX, do 1939 roku, „Przegląd Kalwaryjski” 13(2009).

GoścıŃski R., Prymas Polski wśród Polonii duńskiej, „Kurjer Poznański” 25 sierpnia 1932.

GoścıŃSKi R., Wśród Polonii duńskiej, „Kurjer Poznański” 2 kwietnia 1932. 
Harcerze polscy wracają do Danji, „Narodowiec” 29 sierpnia 1926.

Hergenröther J., Historia Powszechna Kościoła katolickiego, t. XVIII i XIX, Warszawa 1905.

Jak żyją wychodźcy polscy w Danji. Pierwsze posiedzenie Rady Naczelnej Związku Robotników Polskich w Danji, „Narodowiec” 8 lutego 1928.

Jak żyje wychodztwo polskie w Danji, „Narodowiec” 27 listopada 1926.

JĘDrZejowski A., Polonia duńska w latach 1892-1921, „Przegląd Polonijny” 1(1975), z. 2, s. 17-31.

Jubileusz pasterza wychodźców polskich w Danii, „Głos Seminarium Zagranicznego” 1935, nr 4.

JuDYCKi Z.A., Polscy duchowni w świecie. Słownik biograficzny, Kielce: Redakcja Informatorów Biograficznych 2008.

K.R., Z wychodztwa polskiego w Danji, „Narodowiec” 7 sierpnia 1926.

K.R., Z wychodztwa polskiego w Danji, „Narodowiec” 10 sierpnia 1926.

K.R., Z wychodztwa polskiego w Danji, „Narodowiec” 25 sierpnia 1926.

K.R., Uroczystość św. Ansgara. - Udział wychodzców, „Narodowiec” 13 sierpnia 1926.

KĄDZIOŁA I., Z życia robotników polskich w Danji, „Narodowiec” 20 lipca 1926.

KLesSEns J.P. Ks., Do moich Rodaków koło Maribo w Danji, z kolendą, „Narodowiec” 18 grudnia 1926.

KoŁodzIEJ B., Opieka duszpasterska nad wychodźcami polskimi do roku 1939, Poznań: UAM 2003.

KoŁodzIEJ E., Wychodźstwo zarobkowe z Polski 1918-1939. Studia nad polityką emigracyjną II Rzeczypospolitej, Warszawa: Książka i Wiedza 1982.

Kościelecka S., Dzieje Polonii w Danii w latach 1892-1940, Szczecin: Wydawnictwo Naukowe WSP w Szczecinie 1983.

Kożuch W., Polacy w Danii. Obca opieka duszpasterska a ojczysta nad Polakami w Danii, „Robotnik” - dodatek do „Gazety Grudziądzkiej” 9 sierpnia 1933.

KRUSzEwsKi E.S., Jak redemptorysta „stawał w potrzebie” o. Jan Tomasz Szymaszek (1901-1989), „Rocznik Instytutu Polsko-Skandynawskiego” 17( 2001/2002).

Kruszewski E.S., Pastor Edward Ortved (1855-1930) og Hans breve til biskop Johannes von Euch fra 1894-1906. Ksiądz Edward Ortved (1855-1930) oraz listy z lat 1894-1906 do bp. Johannes von Eucha, Kobenhavn 2003.

Kruszewski E.S., Pastor Edward Ortved (1855-1930) - opiekun Polaków w Danii, „Acta Cassubiana" 4(2002).

KrUSZEwSKi E.S., Położenie katolików w krajach skandynawskich od pierwszej połowy XVI do połowy XIX wieku. Zarys, ,Rocznik Instytutu Polsko-Skandynawskiego” (Kopenhaga) 3(1987/1988).

Kruszewski E.S., Problemy osadnictwa Polaków w Danii 1893-1939, Londyn 1980.

KRUSZEwSKi E.S., Śladami polskiego apostolstwa w Danii, [w:] W nieustającej trosce o polską diasporę: tom studiów historycznych i politologicznych dedykowany Księdzu Arcybiskupowi Szczepanowi Wesołemu, red. R. Nir, M. Szczerbiński, K. Wasilewski, Gorzów Wielkopolski: Stowarzyszenie Naukowe „Polska w Świecie” 2012, s. 149-164. 
Kubera H., Ks. Stanisław Lisoń, Wspomnienie (1881-1937), „Gazeta Wyborcza” (Poznań) 15 stycznia 2004.

LATER-ChODYŁowa E., Liczebność i rozmieszczenie emigracji polskiej w Danii w latach 1893-1940, „Przegląd Polonijny” 17(1991), z. 3, s. 19-30.

Later-Chodylowa E., Przegląd literatury na temat dziejów Polaków i Polonii w Danii, „Przegląd Polsko-Polonijny”3(2012), z. 3, s. 279-302.

Malanowski J., Adaptacja Polaków w Danii, „Problemy Polonii Zagranicznej” 1(1961), s. 124-154.

Mytkowicz A., Powstanie i rozwój emigracji sezonowej, Kraków 1917.

Nellemann G., Polscy robotnicy rolni w Danii, „Przegląd Polonijny” 9(1985), z. 1, s. 5-30.

Nellemann G., Polska emigracja zarobkowa w Danii od r. 1893, „Przegląd Zachodni” 29(1973), z. 1, s. 41-71.

Nie damy sobie wydrzeć ani ducha polskiego ani polskiej mowy, „Narodowiec” 27 września 1926.

O emigracji polskiej w Danji, „Kurjer Lwowski” 6 listopada 1901, nr 308, s. 4.

OкоŁowicz J., Wychodźstwo i osadnictwo polskie przed wojną światową, Warszawa 1920.

OLSZEWski E., Emigracja polska w Danii 1893-1993, Warszawa-Lublin: ISP PAN 1993.

Olszewski E., Polska Misja Katolicka w Danii i jej duszpasterze - organizatorzy, [w:] Duchowieństwo polskie w świecie. Materiały VII Międzynarodowego Sympozjum Biografistyki Polonijnej. Papieski Uniwersytet Urbaniański. Rzym, 17-18 października 2002 r., red. A. i Z. Judyccy, Toruń: Oficyna Wydawnicza Kucharski 2002.

OlsZewski E., Z problemów życia narodowego Polonii duńskiej, [w:] Polacy w Skandynawii, red. E. Olszewski, Lublin: Wydawnictwo Panta 1997.

Olszewski E., Związek Polaków - katolików w Danii (1918-1919), „Studia Polonijne” 14(1992).

Opieka kulturalna nad emigracją polską w Belgji, „Biuletyn Komitetu Opieki Kulturalno-Społecznej dla Wychodztwa Polskiego w Belgji” czerwiec 1927.

Opieka religijna nad Polakami w Holandji i Danji, „Biuletyn Komitetu Opieki Kulturalno-Społecznej dla Wychodztwa Polskiego w Belgji” czerwiec 1927.

OwCZARSKi A. CSsR, Bibliografia redemptorystów polskich (1883-2008), Kraków 2009.

Pitoń J. CM, Księża polscy w Brazylii 1848-1984, [w:] Zmagania polonijne w Brazylii, t. IV: Owocująca przeszłość, red. T. Dworecki SVD, Warszawa: ATK 1987.

PodGórski A., Z wychodztwa polskiego w Danji, Obchód „Cudu nad Wisłą” w Koge, „Narodowiec" 2 września 1926.

Podręczna Encyklopedia Kościelna, t. XIII-XIV, Warszawa 1907.

Polacy w Danji, „Kurjer Lwowski” 8 stycznia 1902, nr 8.

Polacy w Danji. (Rozmowa współpracownika „Gazety Polskiej” z księdzem Ortvedem), „Kurjer Lwowski” 15 lutego 1903, nr 46.

Polacy w Skandynawii, red. E. Olszewski, Lublin: Wydawnictwo Panta 1997, s. 99-163.

Polscy robotnicy w Danii, „Przegląd Emigracyjny” 1 września 1892, nr 5.

Powrót polskich robotnic sezonowych z Danji do kraju, „Narodowiec” 16 stycznia 1927.

Robotnicy polscy w Danji i Szwecji, „Kurjer Lwowski” 21 lipca 1908, nr 336. 
Robotnicy polscy w Danji. (Wywiad z dyr. Okołowiczem), „Kurjer Lwowski” 30 września 1910.

Rocznik Służby Zagranicznej Rzeczypospolitej Polskiej według stanu na 1 kwietnia 1938, Warszawa 1938.

RuDNIK W., Co polski harcerz z Danji widział w Polsce?, „Narodowiec” 24 września 1926.

STASIAK A., Opieka duszpasterska nad polską emigracją zarobkową w Danii w latach 1893 1939, Kraków 1982.

STECKo K., Gościński Ludwik, [w:] Słownik biograficzny działaczy polskiego ruchu robotniczego, red. F. Tych [i in.], t. II, Warszawa: Książka i Wiedza 1987.

SzYmaŃSKi J., Duszpasterze Polonii i Polaków za granicą. Słownik biograficzny, t. I, Lublin: Miejska i Powiatowa Biblioteka Publiczna w Kolbuszowej 2010.

SzYMAŃSKI J., Obraz duszpasterstwa polskojęzycznego w Europie na podstawie wizytacji rektora Polskiej Misji Katolickiej w Belgii, „Archiwa, Biblioteki i Muzea Kościelne” 97(2012).

SzYMAŃSKi J., Opieka duszpasterska nad Polakami w Szwecji, „Studia Polonijne” 29(2008).

SzYMAŃski J., Z dziejów opieki duszpasterskiej nad Polakami w Danii w 1927 roku, „Studia Polonijne" 33(2012).

SzYmaŃski J., Związek Robotników Polskich w Danii w trosce o zachowanie tożsamości narodowej rodaków w 1933 roku, „Studia Polonijne” 34(2013).

SzymaszeK J., Duszpasterstwo polskie w Danii. Szkic historyczny, „Duszpasterz Polski Zagranicą" 25(1974), z. 2(111).

SzYmbor W., Wśród wychodźców naszych w Danii, „Roczniki Obydwóch Zgromadzeń Św. Wincentego a Paulo" (Kraków) 20(1914), z. 1.

Trzeba zgodnie i świadomie dążyć do celu: zachowania polskości, „Narodowiec” 15 sierpnia 1926.

Wasılkowski J., Na rzecz wolnej Polski. Towarzystwo Polskie w Danii i jego poprzednicy 1973-2001, Kopenhaga 2002.

Witkowski S., „Polak w Danii” 1918-1919, „Kwartalnik Historii Prasy Polskiej” 25(1986), z. 3.

WRóBEL A.H. OFM, Historia duszpasterstwa polskiego w Argentynie w latach 1897-1997, Buenos Aires 2002.

Wychodźcy polscy w Danji domagają się od rządu polskiego polskich nauczycieli i księży, „Narodowiec” 27 stycznia 1927.

Wychodźtwo polskie w Danji, „Kurjer Lwowski” 30 lipca 1894.

Wychodztwo polskie w Danji, „Narodowiec” 27 czerwca 1926.

Zadania Związku Robotników na najbliższą przyszłość, „Narodowiec” 18 sierpnia 1926.

Zdunek W., Duszpasterstwo Polaków w Danii (1893-1978), „Studia Polonijne” 5(1982).

Zmiany w duchowieństwie, „Dwutygodnik Dyecezjalny Wileński” 10 lipca 1911, nr 13.

Zwiercan A. OFMConv, Działalność Franciszkanów wśród Polonii, „Studia Polonijne” 3(1979). 


\section{OPIEKA DUSZPASTERSKA NAD POLAKAMI W DANII}

(1892-1939)

\section{Streszczenie}

Do Danii emigranci polscy zaczęli przybywać od 1892 r. Początkowo emigracja była sezonowa i miała charakter rolniczy. Na ogólną liczbę 25 tys. katolików w Danii Polaków było 13 tys. W 1927 r. posługę duszpasterską wśród nich spełniało czternastu narodowościowo obcych duszpasterzy, którzy władali językiem polskim. Opieka duszpasterska kapłanów polskich zależnych od prymasa Polski napotykała niezwykły opór szowinistycznie usposobionych misjonarzy, z pochodzenia przeważnie Holendrów i Niemców.

Kościół w Danii był przeciwny narodowej odrębności Polaków, dążył do ich asymilacji. Polscy kapłani nie mieli żadnych uprawnień duszpasterskich i byli całkowicie uzależnieni od miejscowych duszpasterzy. Zabiegi kardynała A. Hlonda kierowane do wikariusza apostolskiego w Kopenhadze, biskupa J. Bremsa, o dopuszczenie polskich księży do posługi duszpasterskiej nad emigracją polską w Danii pozostały bezskuteczne.

Słowa kluczowe: Polacy w Danii; duszpasterstwo polskojęzyczne-polonijne; organizacje polskie; szkolnictwo polskie

\section{PASTORAL CARE FOR POLES IN DENMARK (1892-1939)}

\section{Sum mary}

Poles began to emigrate to Holland in 1892. At first, these emigrantions were seasonal and of a farm-work nature. Among the 25 thousand Catholics in Holland, about 13 thousand were Poles. In 1927, there were 14 ethnic and national pastoral ministers for these people, and they spoke Polish. The pastoral care of these priests from Poland sent by the Primate was met by great opposition by the chauvinist missionaries who mostly came from Holland and Germany.

The Church in Holland opposed Pole's national rites and tried to assimilate them. Polish priests did not have any pastoral privileges and were completely dependent on local pastors. Cardinal A. Hlond turned to Bishop J. Brems, the apostolic nuntio in Kopenhaggen, to allow Polish priests to serve in pastoral care for the Polish emigrants in Holland, but attempts were unsuccessful.

Key words: Poles in Denmark; Polish-language pastoral ministry; Polish organizations; Polish education 